Development

\title{
Ipsilateral and Contralateral Retinal Ganglion Cells Express Distinct Genes during Decussation at the Optic Chiasm
}

(1) Qing Wang, ${ }^{1,2,4}$ Florencia Marcucci, ${ }^{3}$ Isadora Cerullo, ${ }^{3}$ and ${ }^{\circ}$ Carol Mason ${ }^{3,4}$

DOI:http://dx.doi.org/10.1523/ENEURO.0169-16.2016

${ }^{1}$ Doctoral Program in Neurobiology and Behavior, ${ }^{2}$ Medical Scientist Training Program, ${ }^{3}$ Department of Pathology and Cell Biology, ${ }^{4}$ Department of Neuroscience, College of Physicians and Surgeons, Columbia University, New York, NY 10032

\section{Visual Abstract}

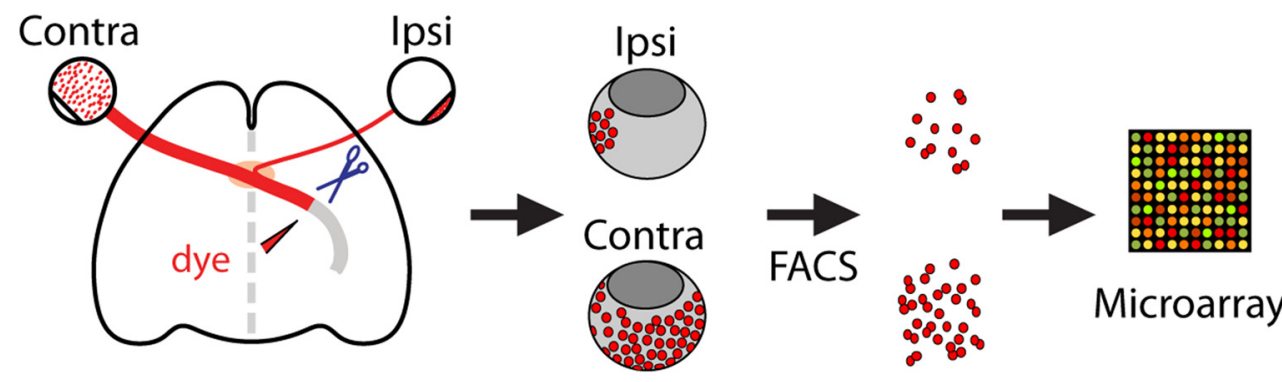

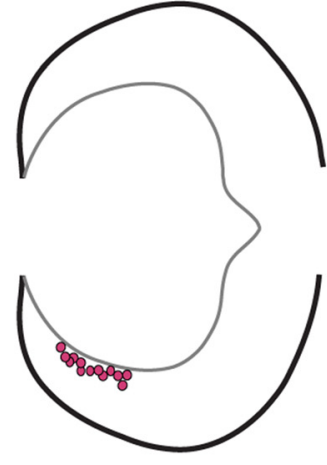

Ipsi
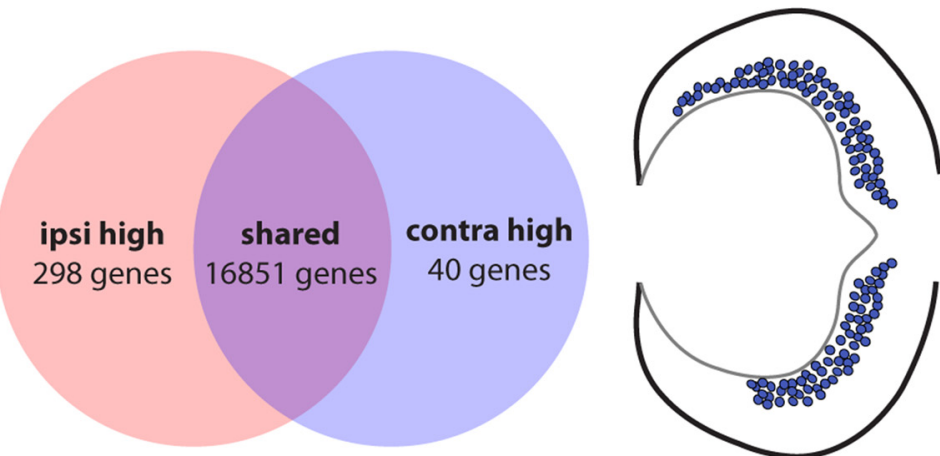

Contra

\section{Significance Statement}

This study presents a new method for isolating ipsilaterally and contralaterally projecting retinal ganglion cells (RGCs) via retrograde labeling and fluorescence-activated cell sorting. The subsequent transcriptomic analysis of these purified populations by microarray, followed by in vivo expression validation, revealed that ipsilateral RGCs have a distinct set of genes that govern neurogenesis, differentiation, and axon guidance compared with contralateral RGCs. Elucidating these gene programs contributes to our understanding of how decussating systems-in particular, the binocular circuit-are established. This information is critical for directing the appropriate RGC subtype differentiation and axon regeneration for repair after injury. 
The increasing availability of transcriptomic technologies within the last decade has facilitated high-throughput identification of gene expression differences that define distinct cell types as well as the molecular pathways that drive their specification. The retinal projection neurons, retinal ganglion cells (RGCs), can be categorized into distinct morphological and functional subtypes and by the laterality of their projections. Here, we present a method for purifying the sparse population of ipsilaterally projecting RGCs in mouse retina from their contralaterally projecting counterparts during embryonic development through rapid retrograde labeling followed by fluorescence-activated cell sorting. Through microarray analysis, we uncovered the distinct molecular signatures that define and distinguish ipsilateral and contralateral RGCs during the critical period of axonal outgrowth and decussation, with more than 300 genes differentially expressed within these two cell populations. Among the differentially expressed genes confirmed through in vivo expression validation, several genes that mark "immaturity" are expressed within postmitotic ipsilateral RGCs. Moreover, at least one complementary pair, Igf1 and Igfbp5, is upregulated in contralateral or ipsilateral RGCs, respectively, and may represent signaling pathways that determine ipsilateral versus contralateral RGC identity. Importantly, the cell cycle regulator cyclin D2 is highly expressed in peripheral ventral retina with a dynamic expression pattern that peaks during the period of ipsilateral RGC production. Thus, the molecular signatures of ipsilateral and contralateral RGCs and the mechanisms that regulate their differentiation are more diverse than previously expected.

Key words: cell specification; contralateral; decussation; ipsilateral; optic chiasm; retinal ganglion cell

\section{Introduction}

The vertebrate central nervous system is composed of a complex network of highly diverse neurons defined by distinct molecular signatures that confer their unique properties in morphology, connectivity, and function. The vertebrate retina, with its three cellular layers and six neuronal classes, has been a useful model for studying general principles of neurogenesis and axon guidance. Each class of retinal cells can be further divided into morphologically and functionally distinct subtypes, and recent efforts have identified the molecular programs that establish these differences within neuronal classes, such as amacrine, bipolar, and retinal ganglion cell (RGC) subtypes (Kim et al., 2008; Badea et al., 2009; Kay et al., 2011a, 2011b; Watson et al., 2012; Jiang et al., 2013;

Received June 18, 2016; accepted November 8, 2016; First published November 17, 2016.

The authors declare no competing financial interests.

Author contributions: QW designed experiments, collected and analyzed data, and wrote the paper; FM collected data for the Foxd1 KO experiments and contributed to writing; IC assisted with the in situ expression studies; CM designed research and wrote the paper with QW.

Supported by NIH grants R01 EY012736 and EY015290 (CM) and T32 GM07367 and EY013933 (QW) and Fight for Sight (FM).

Qing Wang's present address: Department of Ophthalmology, Jules Stein Eye Institute, University of California at Los Angeles, Los Angeles, CA 90095.

Acknowledgments: We thank Takaaki Kuwajima for help with retrograde labeling experiments, Mika Melikyan for mouse breeding and genotyping, Alexandra Rebsam (INSERM, Paris) for advice on gene profiling experiments, Fiona Doetsch and lab for advice on microarray analysis, Paola Arlotta (Harvard) for advice in the early stages of ISH probe design, and Jane Dodd and members of the Mason lab for discussion and comments on the manuscript.

Correspondence should be addressed to either of the following: Carol Mason, Department of Pathology and Cell Biology, College of Physicians and Surgeons, Columbia University. 14-509 P\&S Bldg., 630 W. 168th St., New York, NY 10032. E-mail: cam4@columbia.edu; or Qing Wang, UCLA Stein Eye Institute, 100 Stein Plaza, Los Angeles, CA 90095. E-mail: qwang@jsei.ucla.edu.

DOI:http://dx.doi.org/10.1523/ENEURO.0169-16.2016

Copyright (C) 2016 Wang et al.

This is an open-access article distributed under the terms of the Creative Commons Attribution 4.0 International, which permits unrestricted use, distribution and reproduction in any medium provided that the original work is properly attributed.
Sajgo et al., 2014; Macosko et al., 2015; Osterhout et al., 2015; Sanes and Masland, 2015; Tang et al., 2015; Jin et al., 2015; Rousso et al., 2016; Shekhar et al., 2016). RGCs, as the only projection neurons of the retina, can be additionally distinguished by the laterality of their axonal projection to targets in the thalamus and midbrain. It is this decussation of the retinogeniculate projection that underlies binocular vision.

Two different guidance programs direct the growth of the ipsilateral and contralateral projections at the mouse optic chiasm: EphB1 and EphrinB2 interactions repel ipsilateral axons from the midline, and an NrCAM/PlexinA1 complex reverses an inhibitory Sema6D signal to promote contralateral axon growth through the midline (Williams et al., 2003, 2006b; Kuwajima et al., 2012). Of the known retinal guidance receptors potentially regulated by these transcriptional programs, knockout mouse models show only partial changes in laterality (Williams et al., 2003, 2006a; Erskine et al., 2011; Kuwajima et al., 2012). Moreover, the molecular interactions between transcription factors (e.g., Zic2 and Islet2), downstream effectors (e.g., EphB1, Neuropilin, NrCAM, and PlexinA1), and upstream patterning genes (e.g., Foxd1 and Foxg1) within this genetic network have proven difficult to identify, suggesting the presence of yet-unknown intermediate players that bridge these gaps (Herrera et al., 2003, 2004; Pak et al., 2004; Pratt et al., 2004; Tian et al., 2008; Picker et al., 2009; Carreres et al., 2011; Fotaki et al., 2013; HernandezBejarano et al., 2015). For example, in overexpression studies, Zic2 is more potent than EphB1 in switching RGC projection laterality (Petros et al., 2009b) and thus may regulate additional downstream factors in the uncrossed guidance program. Even less is known about the transcriptional regulators and adhesion molecules that mediate organization of eye-specific RGC axon cohorts in the optic tract and innervation of target regions.

One approach to tackling these questions is to analyze the molecular signatures of ipsilateral and contralateral RGCs to identify genes specific to these two RGC subtypes. Such an approach has proven useful in recent 
studies of other neuronal subtypes, such as cortical projection neurons (Lodato and Arlotta, 2015), and has been particularly successful in uncovering transcriptional networks that regulate postmitotic cell fate acquisition. An unbiased screen allows for identification of new candidates not previously described in other systems and not ascribed to the retina or RGCs. A challenge to such studies is that ipsilateral RGCs constitute a very small population of cells within the retina [only $\sim 3-5 \%$ of the final RGC number and $\sim 10 \%$ at embryonic day 16.5 (E16.5)]. Thus, the ipsilateral RGC population is particularly sensitive to contamination by other cell types when using anatomical isolation approaches.

Here we present a novel method for purifying embryonic ipsilateral and contralateral RGCs using retrograde labeling of live tissue coupled with fluorescence-activated cell sorting (FACS). Through gene expression profiling of purified ipsilateral and contralateral RGCs during the critical period of axon outgrowth and midline decussation, we have uncovered distinct molecular signatures that define and distinguish these two RGC cohorts during embryonic development. Through subsequent validation of the in vivo expression patterns of select candidates, we have identified more than $\mathbf{3 0 0}$ genes that are differentially expressed in ipsilateral and contralateral RGCs. Ipsilateral RGCs are enriched in "early" genes, in particular transcription factors known to be expressed by retinal progenitor cells. Of special interest is the expression of cyclin D2, a cell cycle-related gene highly abundant in ventral retina. In addition, we observed the expression of potential molecular partners in a complementary fashion within ipsilateral and contralateral RGCs. Although several important studies have identified genes that distinguish neuronal subtypes defined by their connectivity or neurotransmitter expression, this is the first attempt at using gene profiling to investigate the differences between two neuronal subtypes distinguished by the laterality of their projection.

\section{Materials and Methods}

\section{Animals}

C57/BL/6J mice were obtained from the Jackson Laboratory (Bar Harbor, ME) and are referred to as wild-type in this study. In Foxd1 1acz/+ and Foxd1 1acz/lacz mice, the lacZ gene was substituted for the coding region of Foxd1 (Hatini et al., 1994). Mice were housed in a barrier facility in a timed-pregnancy colony at Columbia University and exposed only to conditions and procedures that were approved by the Institution Animal Care and Use Committee, protocol numbers AAAG8702 and AAAG9259. Females were checked for vaginal plugs at approximately noon on every weekday. Conception was assumed to take place at midnight, and E0.5 refers to the day on which the vaginal plug was detected.

\section{Retrograde labeling}

Tetramethylrhodamine-conjugated dextran MW3000, anionic, lysine fixable (D-3308; Invitrogen, San Diego, CA) was used to retrogradely label retinal ganglion cells. Pregnant females were anesthetized using ketamine-xylazine
(100 and $10 \mathrm{mg} / \mathrm{kg}$, respectively, in $0.9 \%$ saline). While the mother was kept alive, each E16.5 embryo was removed from the uterus and decapitated in DMEM/F12 (Invitrogen) buffer over ice. The head was immersed in DMEM, and hard palate and skull base were removed to expose the optic chiasm and tract. The optic tract and surrounding tissue were dried, and a pinch of dextran was applied to the severed optic tract with forceps. Heads were then incubated in pre-oxygenated bubbling artificial CSF at room temperature for 2 hours.

For FACS experiments, retinas were immediately dissected out without fixation and were screened for labeling with rhodamine in the expected domains for ipsilateral and contralateral RGCs. Only retina pairs with robust and specific rhodamine labeling were processed for FACS.

For whole-mount preparations, labeled heads were fixed in $4 \%$ PFA in $0.1 \mathrm{~m}$ phosphate buffer (PB) at $4^{\circ} \mathrm{C}$ overnight and rinsed in PBS. Retinas were then dissected and flat-mounted on coverslipped slides with Fluoro-Gel (Electron Microscopy Sciences, Hatfield, PA).

\section{Fluorescence-activated cell sorting}

Dissected ipsilateral or contralateral retinas were digested in papain solution $(20 \mathrm{U} / \mathrm{mL}$ in Earle's balanced salt solution, Worthington, Freehold, NJ) followed by repeated trituration in DMEM/F12 + 10\% fetal bovine serum + DNasel. Dissociated cells were washed with PBS, resuspended in PBS $+2 \%$ fetal bovine serum, passed through a $0.45-\mu \mathrm{m}$ cell strainer, and kept on ice before and throughout flow cytometry. Rhodamine-positive neurons, with exclusion of DAPI-stained dead cells, were collected using a BD FACSAria cell sorter in the Columbia University Cancer Research Center core facility.

\section{RNA extraction}

RNA purification was performed immediately after FACS using the Absolutely RNA Nanoprep kit (Stratagene, La Jolla, CA). RNA concentration was determined using the RNA 6000 Pico kit (Agilent Technologies, Santa Clara, CA) with the Agilent 2100 Bioanalyzer and stored at $-80^{\circ} \mathrm{C}$.

\section{Microarray preparation and analysis}

Amplified cDNA was generated from purified RNA using Ovation Pico WTA System (Nugen, San Carlos, CA) and labeled and fragmented using the Encore Biotin Module (Nugen). For each round of FACS isolation, the same amount of starting RNA extracted from the ipsilateral or contralateral RGC populations was used for CDNA amplification. Labeled cDNA $(5 \mu \mathrm{g})$ was hybridized on Mouse Genome 4302.0 Array chips (Affymetrix, Santa Clara, $\mathrm{CA}$ ), and analyzed using GeneSpring GX11 (Agilent Technologies). Differentially expressed genes were identified from three biological replicates (three independent rounds of retrograde labeling and FACS) by greater than two-fold change and corrected $p<0.05$, Benjamini-Hochberg. Microarray data was deposited in NCBl's Gene Expression Omnibus and are accessible through GEO series accession number GSE83461 (https://www.ncbi.nlm.nih.gov/geo/ query/acc.cgi?acc $=$ GSE83461). 
Table 1. Primers used in qRT-PCR and for generating in situ hybridization probes.

\begin{tabular}{|c|c|c|c|}
\hline Gene & Forward Primer & Reverse Primer & Amplicon Size (bp) \\
\hline \multicolumn{4}{|l|}{ Used in RT-PCR } \\
\hline Zic2 & GCATGTCCACACCTCAGATAAG & ATGGACCTTCATGTGCTTCC & 324 \\
\hline Slc6a4 (SERT) & GCTGAGATGAGGAACGAAGAC & GAGGAAGAAGATGATGGCAAAG & 1240 \\
\hline Gja1 & TACCCAACAGCAGCAGACTTT & AAATGAAGAGCACCGACAGC & 240 \\
\hline Klf4 & СССААСТАСССТССТТТССТ & AGGTTTCTCGCCTGTGTGAGT & 2175 \\
\hline Lhx2 & GCGAATACCCAGCACACTTT & TGTTCAGCATCGTTCTCGTT & 235 \\
\hline Otx2 & GTTCCGTCACTCCAAATCTACC & GTCCTCTCCCTTCGCTGTTT & 248 \\
\hline Sox2 & GTTACСТСТTССТСССАСТССА & CTTCTCCAGTTCGCAGTCCA & 216 \\
\hline Sparc & GACTCTTCCTGCCACTTCTTTG & AGGTTGTTGCCCTCATCTCTCT & 1454 \\
\hline Zfp36 & CCCATCTTCAATCGTATCTCTG & CTGTCAACTGTCTCCCTCAAAC & 1765 \\
\hline Zic1 & GCAAGATGTGCGATAAGTCC & GTGGTCGGGTTGTCTGTTGT & 744 \\
\hline Semaße & CCAACTCCTCCTTTGTGTCC & TCATCTCGGTCTTCGTTATCAG & 2570 \\
\hline$T b \times 20$ & ATTGAGAGGGAGAGTGTGGAGA & ACGATACCCAGGAACTGAGAGA & 1338 \\
\hline Hprt & AGCAGGTGTTCTAGTCCTGTGG & ACGCAGCAACTGACATTTCTAA & 101 \\
\hline \multicolumn{4}{|c|}{ Used for generating ISH probes } \\
\hline Ccnd2 & TCCTGTTTGCCTTCCTTGGAGCCT & ATATGACGGGCTCTGCTTTCCCGT & 566 \\
\hline Fgf12 & GGAGACTTAGGGAACTCGCTGGCA & CACGACCCAAACCCACCCACAAAA & 500 \\
\hline lgf1 & AGCAGATAGAGCCTGCGCAATGGA & CGGGGACTTCTGAGTCTTGGGCAT & 551 \\
\hline lgfbp5 & CTCCAACCCGGAACATGGAGCAAC & GCCCACATAAGGGACAGAGGCTCA & 508 \\
\hline Sox2 & ACAAGGGAATTGGGAGGGGTGCAA & AACCCAGCAAGAACCCTTTCCTCG & 504 \\
\hline$T b \times 20$ & TGGGTGAGCTGACGAGTCTGGATG & TATGATGTGCACCCGTGGCTGGTA & 536 \\
\hline Zic2 & AACCCATCGAGGGCACCTTAGGAT & AGGGAGACTTTGGCACGGCTCATA & 600 \\
\hline
\end{tabular}

\section{Quantitative RT-PCR}

cDNA from E14-E16 retina was retrotranscribed from purified RNA using Superscript III Reverse Transcriptase (Invitrogen). Quantitative PCR (qPCR) was performed using a Stratagene MX3000 with the SYBR Green PCR Kit (Applied Biosystems, Foster City, CA). Transcript levels were normalized to that of HPRT. qPCR-specific primers (Table 1) were designed using the Primer3 program.

\section{Generation of in situ hybridization probes}

Plasmids for making in situ hybridization (ISH) probes were generated for select microarray candidates. cDNA sequences were obtained from NCBI, and PCR primers for generating $\sim 500$-bp riboprobe sequences were selected using Primer-BLAST. 3' sequences of the gene were targeted if possible (Table 5). Template cDNA was synthesized from RNA purified from E14-E16 retina using Superscript III Reverse Transcriptase (Invitrogen), and gene product was generated with targeted oligos and Platinum Pfx polymerase (Invitrogen). PCR product was purified using QIAquick PCR Purification kit (Qiagen, Hilden, Germany), inserted into pCR-Blunt II-TOPO vector using Zero Blunt Cloning kit (Invitrogen), and transformed into TOP10 or DH5 $\alpha$ cells. Purified plasmids were linearized using restriction enzyme with overnight incubation at $37^{\circ} \mathrm{C}$. Riboprobes were synthesized using the Digoxigenin RNA labeling mix (Roche, Basel, Switzerland). The following probe plasmids were obtained from other laboratories: Math5 (L. Gan, University of Rochester), Sema3e (A. Kolodkin, Johns Hopkins University), and Tbx20 (G. Papaioannou, Columbia University).

\section{In situ hybridization of retinal sections}

Embryos were collected at E13.5, E15.5, or E16.5 in PBS on ice. Heads were decapitated in PBS over ice, fixed in $4 \%$ paraformaldehyde (PFA) in $0.1 \mathrm{M} \mathrm{PB}$ at $4^{\circ} \mathrm{C}$ overnight, rinsed in PBS at least three times for a minimum of $1 \mathrm{~h}$ total at $4^{\circ} \mathrm{C}$, and cryoprotected in $30 \%$ sucrose in $0.1 \mathrm{M}$ PBS for $1-2$ nights at $4^{\circ} \mathrm{C}$. Coronal sections $(14-\mu \mathrm{m})$ were collected through the retina and immediately processed for ISH (or stored at $-80^{\circ} \mathrm{C}$ ) using a protocol adapted from Schaeren-Wiemers and GerfinMoser (1993). After ISH, tissues were fixed for $30 \mathrm{~min}$ in $4 \%$ PFA, washed with PBS, and processed for immunostaining with Zic2 and Islet1/2 antibodies.

\section{Antibodies}

The following primary antibodies were used: rabbit anti-Zic2 (RRID:AB_2315623, gift of Stephen Brown, 1:10,000), mouse anti-Islet1/2 (cat. \# 39.4D5, RRID: AB_528173, gift of Thomas Jessell, 1:50; this antibody was raised against Islet1 but also reacts with Islet2), rabbit anti-cyclin D2 (Santa Cruz Biotechnology, Santa Cruz, CA, cat. \# sc-452, RRID:AB_627350, 1:1000), rat anticyclin D2 (Santa Cruz Biotechnology, cat. \# sc-593 RRID: AB_2070794, 1:50), goat anti-Brn3 (Santa Cruz Biotechnology, cat. \# sc-6026 RRID:AB_673441, 1:200), and mouse anti-Brn3a (EMD Millipore, Billerica, MA, cat. \# MAB1585 RRID:AB_94166, 1:200).

The following secondary antibodies were used: donkey anti-rabbit Alexa Fluor488 (Invitrogen, 1:400), donkey anti-mouse Alexa Fluor 488 (Invitrogen, 1:400), donkey anti-goat Alexa Fluor 488 (Invitrogen, 1:400), donkey anti-mouse Cy3 (Jackson Immunoresearch, West Grove, PA, 1:500), donkey anti-rabbit Cy3 (Jackson Immunoresearch, 1:500), donkey anti-goat Cy5 (Jackson Immunoresearch, 1:200), and donkey anti-rat Cy3 (Jackson Immunoresearch, 1:500). 


\section{Immunostaining of retinal sections}

Embryos were collected at the age of interest in PBS on ice. Heads were decapitated in PBS over ice, fixed in 4\% PFA in $0.1 \mathrm{M} P B$ for $1 \mathrm{~h}$ at $4^{\circ} \mathrm{C}$, rinsed in PBS at least three times, washed in PBS for a minimum of $1 \mathrm{~h}$ at $4^{\circ} \mathrm{C}$, and cryoprotected in $10 \%$ sucrose in $0.1 \mathrm{M}$ PBS for $1-2$ nights at $4^{\circ} \mathrm{C}$. Heads were embedded in optimal cutting temperature compound over crushed dry ice and stored at $-80^{\circ} \mathrm{C} .12 \mu \mathrm{m}$ coronal sections were collected for cyclin D2 immunostaining; 16 - to $20-\mu \mathrm{m}$ coronal sections were collected for all other stainings. For immunohistochemistry $(\mathrm{IHC})$, slides were blocked in $10 \%$ normal goat serum (NGS) and $0.2 \%$ Triton X-100 in PBS for $1 \mathrm{~h}$, incubated with primary antibody in $1 \%$ NGS and $0.2 \%$ Triton X-100 in PBS overnight at $4^{\circ} \mathrm{C}$, washed three times for $20 \mathrm{~min}$ in PBS at room temperature, incubated in secondary antibody in $1 \%$ NGS and $0.2 \%$ Triton X-100 in PBS overnight at $4^{\circ} \mathrm{C}$, and washed in PBS three times for 20 min each. Coverslips were mounted on slides with Fluoro-Gel.

\section{Imaging}

$\mathrm{ISH}$ and whole-mount preparations (anterograde and retrograde labeling) were taken by Axiovision software with an Axiophot camera connected to a Zeiss Axioplan2 microscope. IHC preparations were imaged using a Zeiss Axiolmager M2 microscope equipped with Apotome, AxioCam MRm camera, and Neurolucida software (V10.40, MBF Bioscience, Williston, VT).

\section{Results}

\section{Purification of ipsilaterally and contralaterally projecting RGCs}

To identify genes that distinguish ipsilateral and contralateral RGCs during early development through gene expression profiling, pure populations of these two RGC subpopulations from mouse embryonic eyes are needed. To accomplish this, we devised a method of combining retrograde axonal tracing from the optic tract with FACS. In this procedure, the optic tracts are accessed by removal of the palate and exposure of the ventral brain in an isolated head preparation. We then cut the optic tract unilaterally and applied to the cut site a fluorophoreconjugated dextran, which is subsequently transported retrogradely to RGC somas within the ipsilateral or contralateral retina (Fig. 1A). Traditional retrograde labeling approaches for the visual system require long overnight incubations for dye transport. We surveyed a number of commonly used retrograde tracers (including cholera toxin B and dextrans of various molecular weights) and devised a protocol for retrogradely labeling RGCs using rhodamine-dextran 3000 within 2 hours of dye application. These conditions are optimal for preserving tissue health for subsequent cell sorting experiments. As expected, the RGCs labeled within the ipsilateral retina were located in the ventrotemporal (VT) peripheral crescent, whereas extra-VT RGCs were labeled in the contralateral retina as seen in whole mounts (Fig. 1B) and crosssections (Fig. 1C). The fluorescence signal within labeled retinas from two E16.5 litters (12-15 embryos total) was examined, and only retinal pairs with specific and sufficient RGC labeling were used for cell sorting (Fig. 1D).

Pooled ipsilateral and contralateral retinas (8-10 each) were dissociated to obtain a single-cell suspension, and rhodamine-dextran-positive cells were then isolated by FACS. Two litters of retrogradely labeled embryos yielded approximately 3000 FACS events for the ipsilateral population and 20,000 for the contralateral (Fig. 1E). Plating of cells before and after FACS shows enrichment in cells that stain positively for Islet1/2, a marker of differentiated RGCs (Fig. 1F). RGCs were immediately lysed for RNA isolation after FACS, with total time from removal of embryo for retrograde labeling to post-FACS RNA isolation being 8-9 hours. Subsequent qPCR analysis showed that rhodamine-labeled RGCs from ipsilateral retinas express high levels of Zic2 and SERT compared with those from contralateral retinas (Fig. 1G). Thus, rapid retrograde labeling from the optic tract ex vivo followed by FACS is a clean and effective way for purifying ipsilateral and contralateral RGCs during development.

\section{Expression profiling of ipsilateral and contralateral RGCs confirms differential expression of known ipsilateral and contralateral markers and reveals novel differences}

We next conducted expression profiling of ipsilateral and contralateral RGC populations purified using the above methods. Because of the small number of ipsilateral RGCs isolated with this method, cDNA prepared from FACS-isolated ipsilateral and contralateral RGCs was amplified before gene chip hybridization. The three biological replicates from independent rounds of retrograde labeling and FACS that showed the most robust enrichment in Zic2 expression in ipsilateral RGCs by qPCR were selected for microarray analysis. For each round of FACS, paired ipsilateral and contralateral RGCs underwent the same treatment conditions and sample preparation methods.

Gene ontology analysis of microarray results (GEO series accession number GSE83461) revealed that many differentially expressed genes are involved in developmental processes, including regulation of gene expression, cell proliferation, cell cycle progression, and cell differentiation (Table 4). Most genes were expressed at similar levels in ipsilateral and contralateral RGC samples, including the pan-RGC transcription factors Brn3b and Islet1 (Pan et al., 2008). However, 338 genes were differentially expressed in the two populations by two-fold or more (corrected $p$-value $<0.05$, Benjamini-Hochberg; Fig. $2 A, B$, Table 5) and included genes known to be enriched in ipsilateral RGCs such as Zic2 (5.78-fold) and SERT (4.49-fold), as well as contralateral RGC marker Brn3a (2.20-fold). The other known contralateral RGC marker, Islet2, was elevated by only 1.5 -fold and did not make the two-fold cutoff; however, this may be because Islet2 is expressed in only a subset $(\sim 33 \%)$ of contralateral RGCs (Pak et al., 2004).

The microarray gene list also included genes not previously characterized with regard to their differential expression in RGC subpopulations, most of which were 
A

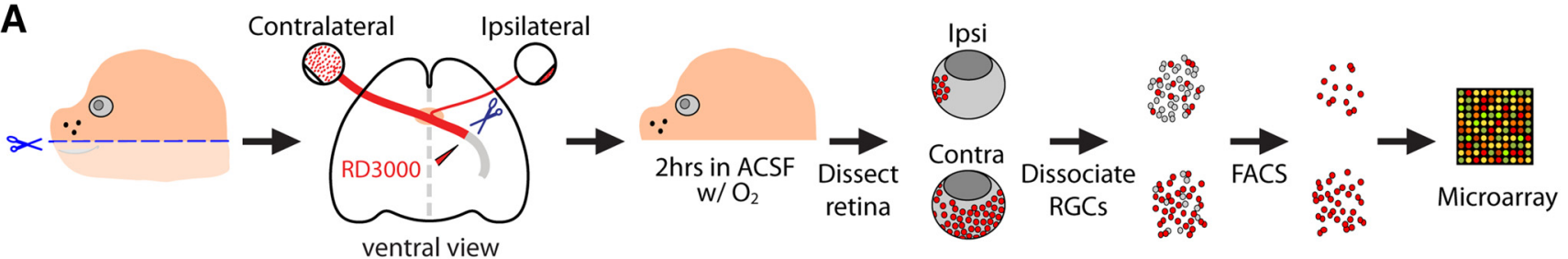

B
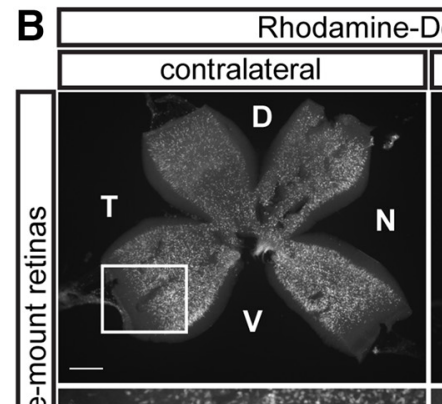

Dextran
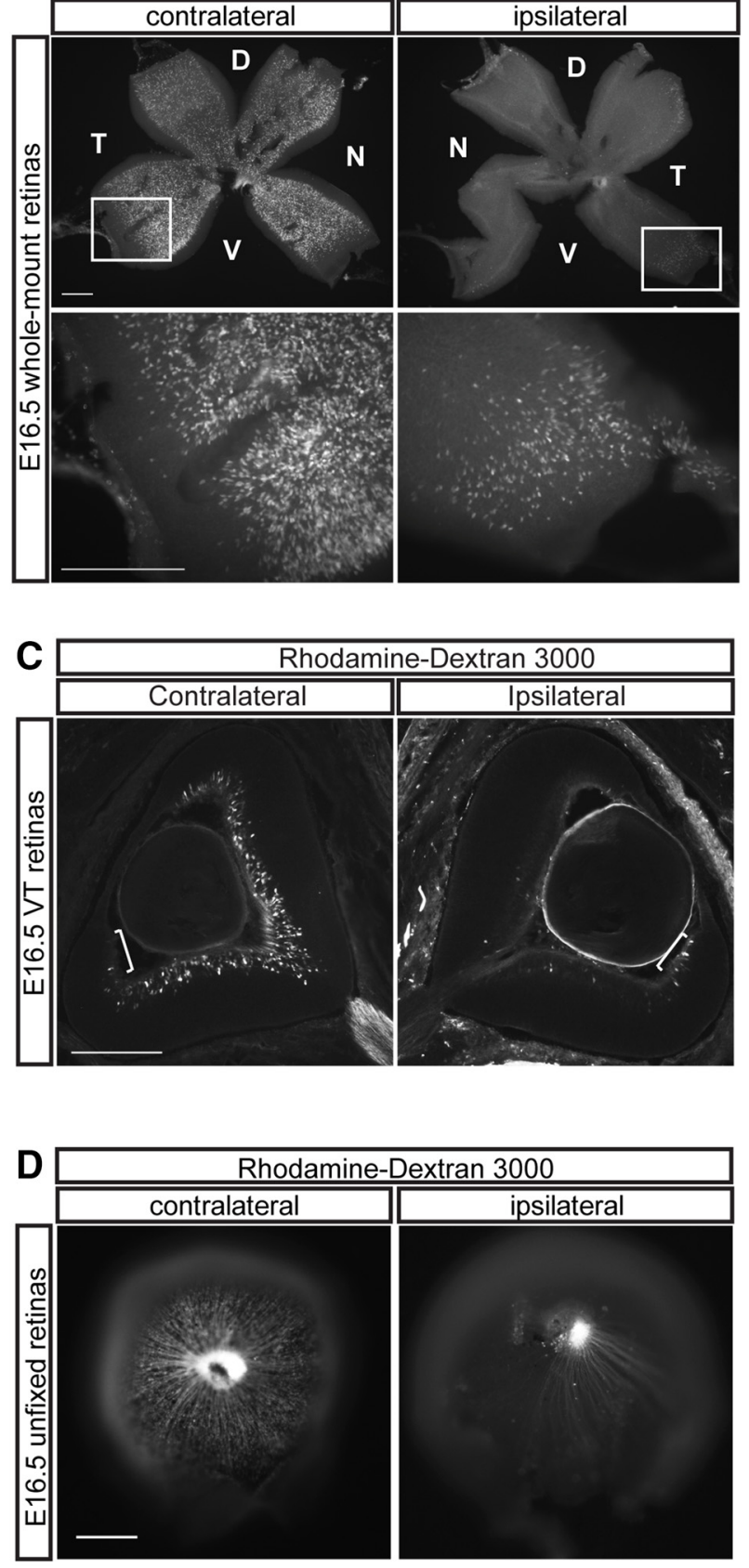

E
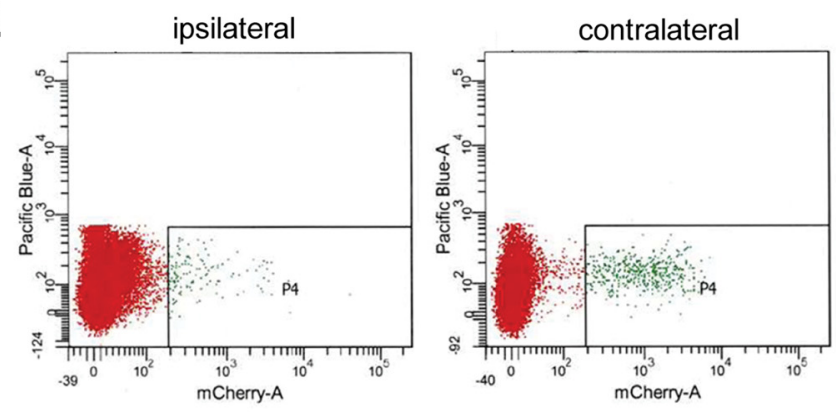

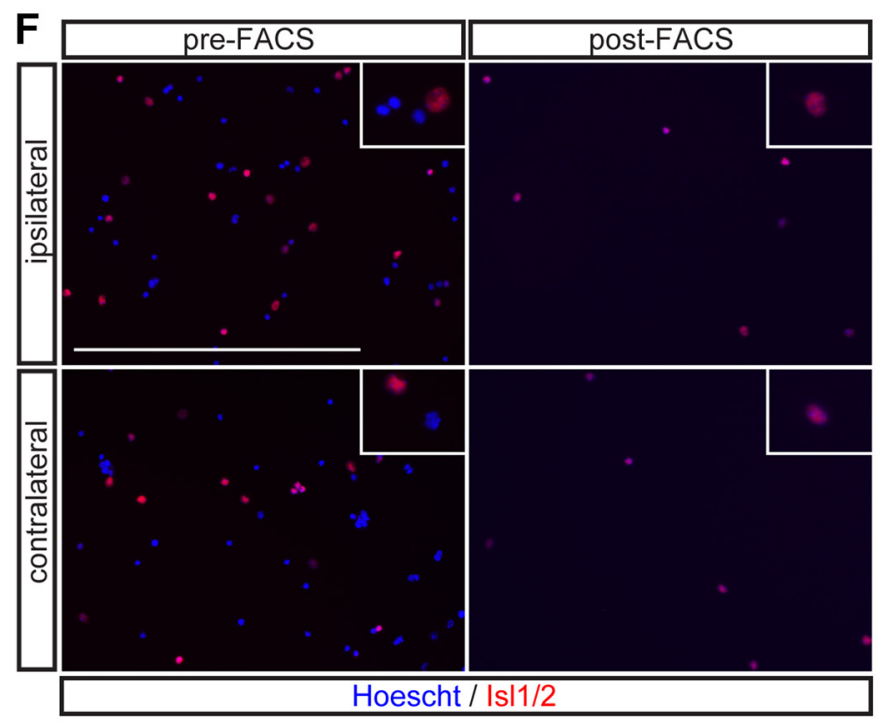

G FACS Sample Purity Analysis

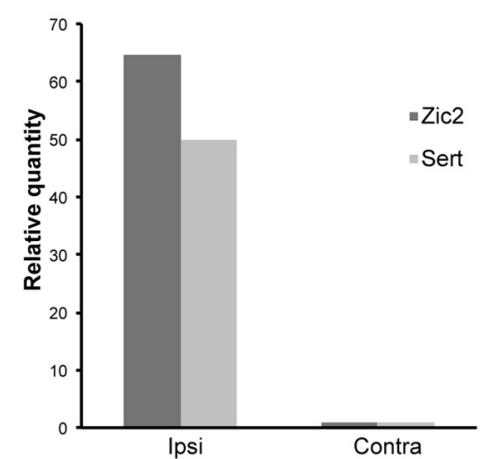

Figure 1. FACS purification of retrogradely labeled mouse retinal ganglion cells at E16.5. A, Schematic of retrograde labeling and cell purification methods for microarray analysis. Diagram of the ventral view of embryonic brain depicts application of rhodamine dextran $3000 \mathrm{MW}$ dye (RD3000) to a unilateral transected optic tract. $\boldsymbol{B}$. Whole-mount preparations of E16.5 retina. RD3000 fully labels axons and cell bodies of E16.5 RGCs within 2 hours of incubation after dye application to the optic tract. Extra-VT RGCs are labeled in retina contralateral to labeled optic tract and VT RGCs are labeled in the ipsilateral retina. C. Coronal vibratome sections of E16.5 retina retrogradely labeled with RD3000 show specific labeling of contralateral and ipsilateral RGCs in their respective retinal domains (VT 
continued

domain marked with white bracket). $\boldsymbol{D}$, Fresh E16.5 retinas are screened for appropriate RD3000 labeling of ipsilateral and contralateral RGCs before FACS. $\boldsymbol{E}$, FACS purification of ipsilateral and contralateral RGC populations retrogradely labeled with RD3000 with DAPI exclusion of nonviable cells. $\sim 3000$ ipsilateral and $\sim 20,000$ contralateral RGCs (P4 gate) are purified from two litters of E16.5 embryos. $\boldsymbol{F}$, Cells purified by FACS are enriched in RGC marker Islet1/2 compared with presorting. G, Zic2 and SERT are enriched in the ipsilateral RGC cell population isolated by FACS compared with the contralateral RGCs. D, dorsal, V, ventral, N, nasal, T, temporal. Scale bars, $250 \mu \mathrm{m}$.

elevated in ipsilateral RGCs (Fig. 2A). In total, 298 genes (404 probe sets) were found to be enriched in ipsilateral RGCs and 40 genes (47 probe sets) in contralateral RGCs, using a two-fold cutoff (Fig. 2, Table 5), suggesting that an extensive genetic program is activated to generate ipsilateral RGCs. An alternative explanation for these findings is that because ipsilateral RGCs reside in a more spatially restricted domain within the retina, some of these genes may have region-specific expression patterns. Moreover, contralateral RGCs represent a much larger cellular population than ipsilateral RGCs in mice, and subsets of contralateral RGCs themselves may have diverse gene expression profiles. Thus, genes that are expressed exclusively in a subset of contralateral RGCs may have been thus missed by our analysis, as in the case of Islet2.

For validation of the microarray, we analyzed the expression levels of 11 new gene candidates (nine ipsilateral high and two contralateral high) in FACS-derived RGCs by quantitative RT-PCR. Of these 11 genes, 10 (all but Otx2) were enriched in the RGC subpopulation as seen by gene profiling, demonstrating interplatform reproducibility of the gene expression detection by microarray (Table 2). In summary, gene profiling of purified ipsilateral and contralateral RGCs at E16.5 revealed that these two RGC subsets are defined by unique molecular signatures and provided an extensive list of candidate genes that may be differentially expressed in these two cell populations.

\section{Selection of differentially expressed gene candidates for in vivo expression validation}

To validate the expression of candidate genes in vivo, we used ISH and IHC, which provide information regarding the spatiotemporal pattern of expression as well as colocalization with known ipsilateral or contralateral RGC markers, such as Zic2, SERT, and Brn3a (Fig. 3). The primary purpose of this microarray screen was to identify additional regulators of axon guidance at the midline and target, including guidance molecules and transcription factors, other genes that functionally distinguish ipsilateral and contralateral RGCs, and finally, genes that specify ipsilateral and contralateral RGC fate. Thus, of the 339 differentially expressed genes, we focused on five groups: transcription factors involved in neuronal development (e.g. Sox2, Lhx2, Math5, Tbx20), signaling pathways prominent during development (e.g. Igf1, Igfbp5, Fgf12, Ptch1), axon guidance-related genes (e.g. Sema3e, Sema4d, Sema5b, Sema7a), cell cycle regulators (e.g., Ccnd1, Ccnd2), and other cell-surface or secreted molecules that may be related to cell differentiation (e.g., Gja1, Sparc, Zip6/Liv-1, Napb). Representative genes of these groups are shown in Table 3.

\section{Genes selectively expressed in contralateral RGCs}

At present, very few specific markers of contralateral RGCs have been identified, and no gene has been shown to specify contralateral identity throughout the retina. To confirm that select candidate genes are indeed specifi-
A

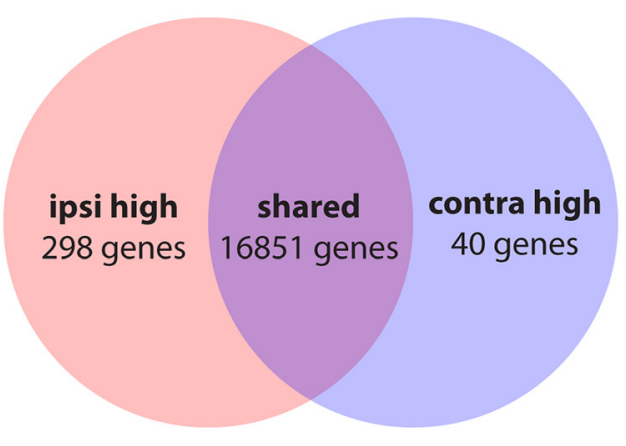

B

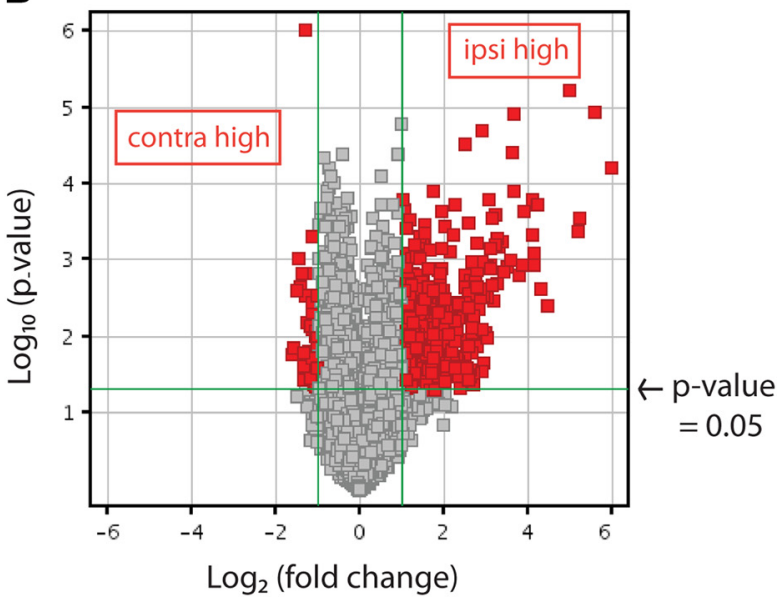

Figure 2. Microarray analysis of ipsilateral and contralateral RGCs purified at E16 reveals distinct expression profiles. $\boldsymbol{A}$, Microarray analysis reveals 298 and 40 unique genes at least two-fold increased in ipsilateral or contralateral RGCs, respectively $(p \leq 0.05$, Benjamini-Hochberg correction). B, Distribution of differentially expressed genes shows that the majority are upregulated in ipsilateral RGCs. 
Table 2. qRT-PCR validation of select microarray candidates shows interplatform reproducibility.

\begin{tabular}{|c|c|c|c|c|}
\hline \multirow[b]{2}{*}{ Gene symbol } & \multirow[b]{2}{*}{ Gene name } & \multicolumn{2}{|c|}{ Microarray } & \multirow{2}{*}{$\begin{array}{l}\text { qPCR } \\
\text { FC }\end{array}$} \\
\hline & & FC & $p$-value & \\
\hline \multicolumn{5}{|c|}{ High in ipsilateral RGCs } \\
\hline Gja1 & Gap junction protein, alpha 1 (connexin 43 ) & 17.60 & 0.001 & $>500$ \\
\hline Klf4 & Kruppel-like factor 4 & 7.38 & 0.002 & 455 \\
\hline Lhx2 & LIM homeobox protein 2 & 4.72 & 0.009 & 2.37 \\
\hline Otx2 & Orthodenticle homolog 2 & 5.02 & 0.021 & 0.651 \\
\hline Slc6a4 & Serotonin transporter (SERT) & 4.49 & 0.004 & 49.8 \\
\hline Sox2 & SRY-box containing gene 2 & 7.47 & 0.029 & 3.81 \\
\hline Sparc & Secreted acidic cysteine rich glycoprotein & 12.47 & 0.000 & 6.02 \\
\hline Zfp36 & Zinc finger protein 36 & 8.28 & 0.002 & 31.2 \\
\hline Zic1 & Zinc finger protein of the cerebellum 1 & 5.67 & 0.002 & 6.49 \\
\hline Zic2 & Zinc finger protein of the cerebellum 2 & 5.78 & 0.016 & 64.7 \\
\hline \multicolumn{5}{|c|}{ High in contralateral RGCs } \\
\hline Sema3e & Semaphorin 3E & -2.20 & 0.003 & -2.52 \\
\hline Tbx20 & T-box 20 & -2.15 & 0.001 & -42.5 \\
\hline
\end{tabular}

Of these 11 genes, all but Otx2 (italicized) were enriched in the RGC subpopulation as seen by gene profiling, demonstrating interplatform reproducibility of the gene expression detection by microarray. Genes previously known to be differentially expressed in ipsilateral and contralateral RGCs are bolded (Zic2, SERT).

cally expressed in contralateral RGCs, we analyzed the mRNA expression pattern of the gene of interest at E15.5 (peak of Zic2 expression) by ISH followed by coimmunostaining with ipsilateral RGC marker Zic2 and pan-RGC marker Islet1/2 within the same sections. We selected these seven genes based on the magnitude of their fold change (Napb, Bmper, and Igf1 were the most highly enriched in contralateral RGCs) as well as their potential function during development as predicted by their known functional classification roles in other systems. Of the seven new contralateral genes tested, the following genes showed exclusive expression in contralateral RGCs (Islet1/2 ${ }^{+} \mathrm{Zic}^{-}$cells): transcription factor Tbx20, cell surface/secreted protein Sema3e, and growth factor Igf1 (Fig. 4A-C). Fgf12 is also enriched in RGCs outside of the $\mathrm{Zic}^{+}$zone and shows only weak expression in VT RGCs (Fig. 4D). Interestingly, Fgf12 and Igf1 expression is weaker in the most peripheral RGCs of

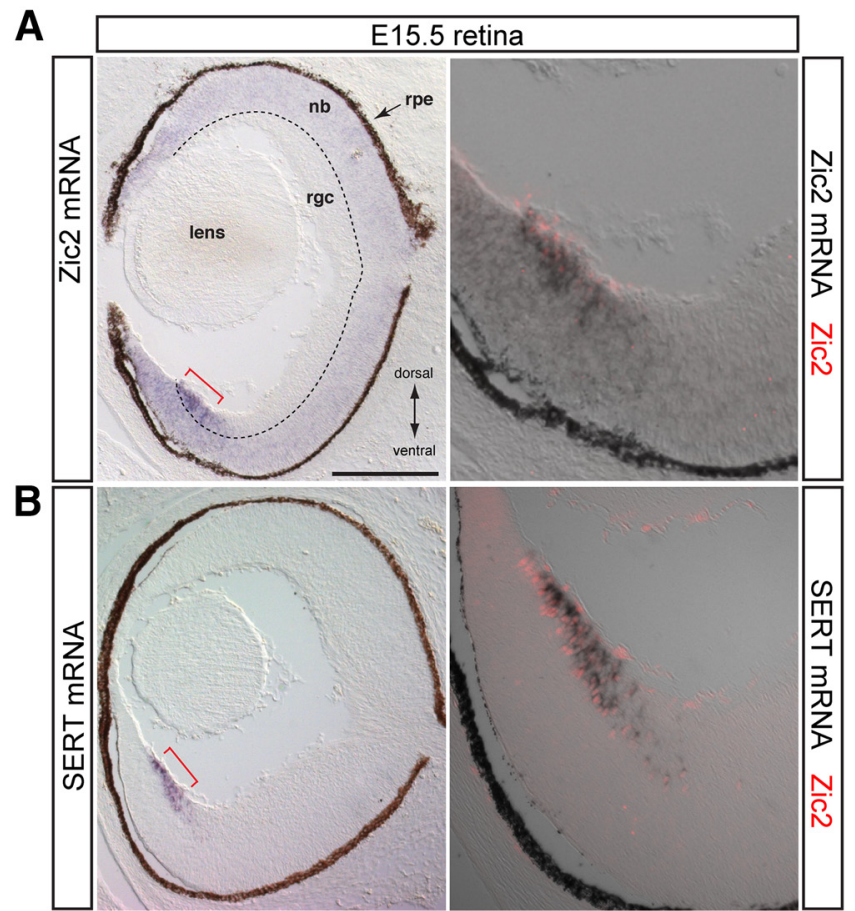

C

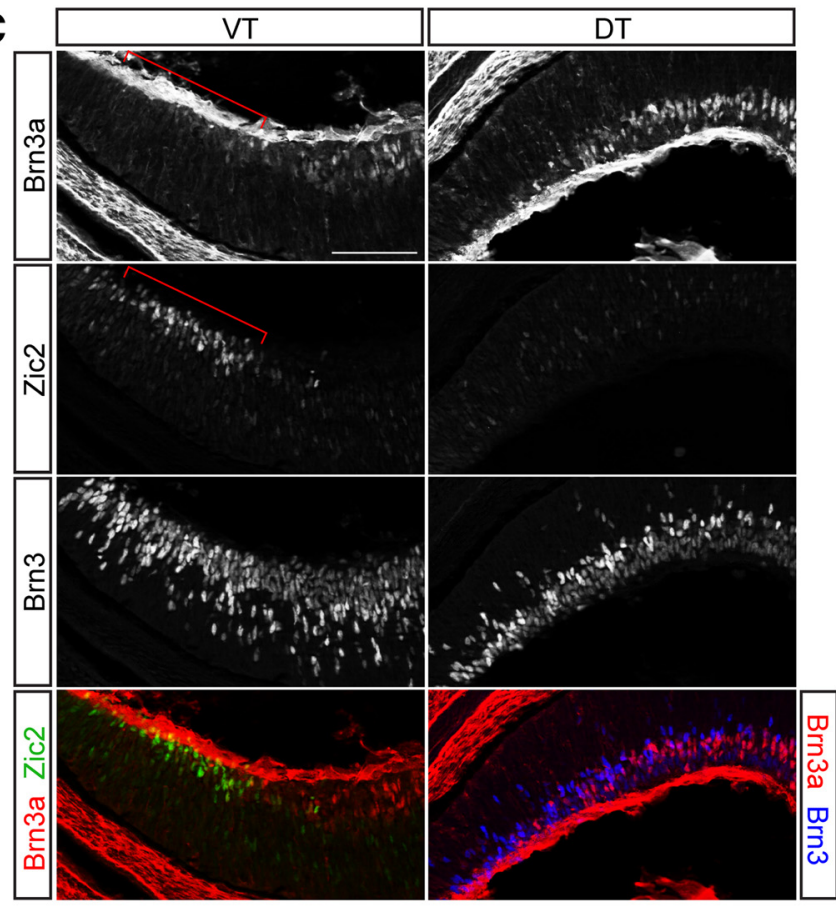

Figure 3. Expression patterns of known ipsilateral and contralateral RGC genes. Combined ISH and IHC analysis at E15.5 shows colocalization of Zic2 protein expression with Zic2 $(\boldsymbol{A})$ and SERT $(\boldsymbol{B})$ mRNA in ipsilateral RGCs in the VT retina. $\boldsymbol{C}$, In contrast, contralateral RGC marker Brn3a shows complementary expression to Zic2 in immunostained sections in which all RGCs are labeled with a pan-Brn3 antibody. These patterns of expression were used as standards for expression analysis of microarray gene candidates. rpe, retinal pigment epithelium; nb, neuroblast layer; rgc, retinal ganglion cell layer; DT, dorsotemporal retina; VT, ventrotemporal retina. Scale bars, $250 \mu \mathrm{m}$ (A and B) and $100 \mu \mathrm{m}(\mathrm{C})$. 
Table 3. Representative genes that are differentially expressed in ipsi- and contralateral RGCs.

\begin{tabular}{|c|c|c|c|c|}
\hline $\begin{array}{l}\text { Function } \\
\text { High in ipsilateral RGCs }\end{array}$ & Gene symbol & Gene name & Fold change & $p$-value \\
\hline \multirow[t]{10}{*}{ Regulation of transcription } & Atoh7 & Atonal homolog 7 (Math5) & 3.87 & 0.010 \\
\hline & Gli3 & GLI-Kruppel family member GLI3 & 3.19 & 0.015 \\
\hline & Klf4 & Kruppel-like factor 4 & 7.38 & 0.002 \\
\hline & Lhx2 & LIM homeobox protein 2 & 4.72 & 0.009 \\
\hline & Neurod4 & Neurogenic differentiation 4 & 6.00 & 0.013 \\
\hline & Otx2 & Orthodenticle homolog 2 & 5.02 & 0.021 \\
\hline & Sox2 & SRY-box containing gene 2 & 7.47 & 0.029 \\
\hline & Sox9 & SRY-box containing gene 9 & 5.69 & 0.003 \\
\hline & Zic1 & Zinc finger protein of the cerebellum 1 & 5.67 & 0.002 \\
\hline & Zic2 & Zinc finger protein of the cerebellum 2 & 5.78 & 0.016 \\
\hline \multirow[t]{3}{*}{ Developmental signaling } & Fzd5 & Frizzled homolog 5 & 5.04 & 0.024 \\
\hline & Notch2 & Notch gene homolog 2 & 6.02 & 0.031 \\
\hline & Tgfb2 & Transforming growth factor, beta 2 & 6.36 & 0.005 \\
\hline Axon guidance & Sema5b & Semaphorin $5 \mathrm{~B}$ & 4.11 & 0.007 \\
\hline Cell cycle control & Ccnd2 & Cyclin D2 & 8.17 & 0.002 \\
\hline \multirow[t]{5}{*}{ Other cellular functions } & Gja1 & Gap junction protein, alpha 1 (connexin 43) & 17.60 & 0.001 \\
\hline & Slc1a3 & Glial high affinity glutamate transporter & 9.47 & 0.002 \\
\hline & Slc2a1 & Facilitated glucose transporter & 3.19 & 0.016 \\
\hline & Slc6a4 & Serotonin transporter (Sert) & 4.49 & 0.004 \\
\hline & Sparc & Secreted acidic cysteine rich glycoprotein & 12.47 & 0.000 \\
\hline \multicolumn{5}{|l|}{ High in contralateral RGCs } \\
\hline \multirow[t]{2}{*}{ Regulation of transcription } & Pou4f1 & POU domain, class 4 , transcription factor 1 (Brn3a) & 2.20 & 0.001 \\
\hline & Tbx20 & T-box 20 & 2.15 & 0.001 \\
\hline Signaling & Bmper & BMP-binding endothelial regulator & 2.83 & 0.002 \\
\hline \multirow[t]{2}{*}{ Axon guidance } & Sema3e & Semaphorin 3E & 2.20 & 0.003 \\
\hline & Sema7a & Semaphorin $7 \mathrm{~A}$ & 2.03 & 0.022 \\
\hline
\end{tabular}

Genes previously known to be differentially expressed in ipsilateral and contralateral RGCs are bolded (Zic2, SERT, Brn3a).

dorsotemporal (DT) retina, suggesting that the youngest DT RGCs (Fig. 4C, D, adjacent to dashed red line) have not yet accumulated as much of these transcripts as the more central RGCs. Tbx20 and Sema3e are even more centrally expressed and appear to have more mosaic expression. None of these genes have been studied in the context of RGC development or contralateral RGC function. Together, Igf1, Fgf12, Tbx20, and Sema3e represent four new contralateral RGC markers during the peak period of axon outgrowth, when ipsilateral and contralateral RGC axons diverge.

\section{Genes selectively expressed in ipsilateral RGCs}

To validate the expression pattern of genes enriched in ipsilateral RGCs in the microarray, we again used ISH analysis on coronal sections of E15.5 retina, coimmunostaining for RGC markers. Here, we selected transcription factors that participate in CNS development as discussed above, as well as cell cycle regulators, developmental signaling molecules, axon guidance molecules, and other secreted or membrane-expressed genes that may play a role in differentiated RGC function. Of the 23 new ipsilateral genes tested, many were expressed in proliferative zones within the retina, as expected. However, three genes, Sox2, Math5, and Igfbp5, were additionally expressed in differentiated ipsilateral RGCs. We also detected four other genes, Lhx2, Zic1, Gja1, and Ccnd2, that were expressed in ipsilateral RGCs either at a weaker level or within a more limited developmental window (data not shown).
The most striking expression pattern of this group of validated genes is that of insulin-like growth factor binding protein 5 (Igfbp5). Igfbp5 is expressed in RGCs of the $\mathrm{Zic2}^{+}$RGC zone throughout the VT retina (Fig $5 A)$. Closer examination reveals that lgfbp5 is most strongly expressed in Zic2 ${ }^{+}$Islet $1 / 2^{+}$RGCs of this region, but not all Zic2 ${ }^{+}$RGCs express Igfbp5, and some Zic2 ${ }^{-}$cells also express lower levels of lgfbp5 and are located at the junction between the RGC and neuroblastic layers (Fig. $5 A$, high power). Igfbp5 is also expressed in the most peripheral contralaterally projecting RGCs (Zic2-Islet1/2 ${ }^{+}$) of DT retina, although these cells are much fewer than the VT RGCs that express Igfbp5. Interestingly, Igfbp $5^{+}$cells correspond to the most peripheral DT RGCs that lack Igf1 expression (Fig. 5B). Thus, Igfbp5 and Igf1 have a complementary pattern of expression in E15.5 retina, suggesting that these two components of the Igf signaling pathway have complementary or antagonistic functions at this age.

To determine whether Igfbp5 is truly related to ipsilateral RGC identity, we studied the expression of Igfbp5 in the Foxd1 knockout, in which the patterning of the region containing ipsilateral RGCs is disrupted with concomitant loss of Zic2-expressing RGCs. Indeed, Igfbp5 coexpression within RGCs is reduced within the VT retina (Fig. $5 C$ ), suggesting that lgfbp5 is not merely expressed in the peripheral-most RGCs but rather is uniquely upregulated within ipsilateral RGCs. 

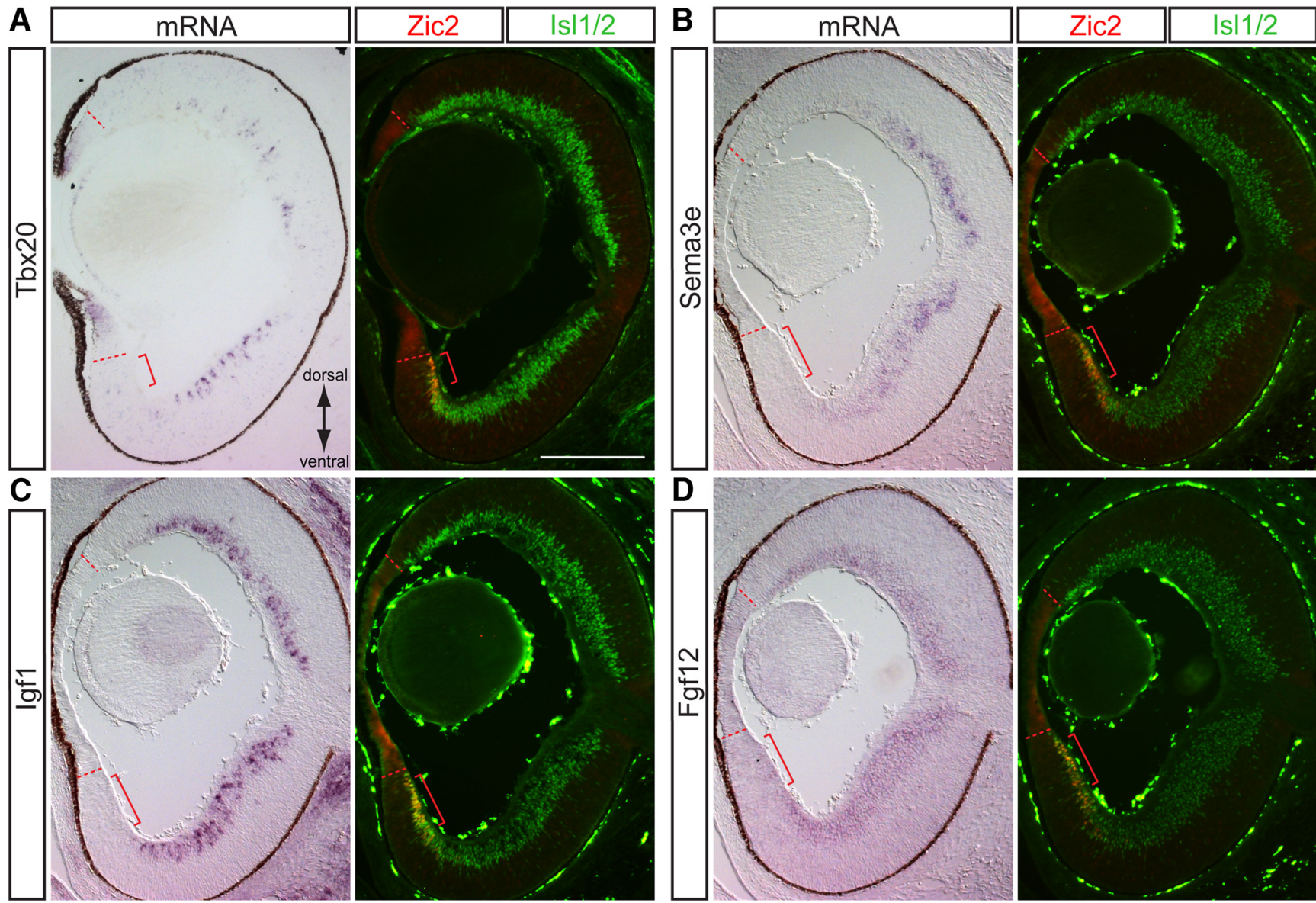

Figure 4. Genes enriched in the contralateral RGC population. ISH analysis at E15.5 shows complementary expression of Tbx20 (A), Sema3e (B), and Igf1 mRNA (contralateral RGCs) with Zic2 (ipsilateral RGCs). Fgf12 is highly expressed in Zic2- RGCs, with only trace levels of expression in Zic2 ${ }^{+}$cells. All candidate genes are expressed in Islet1/2 ${ }^{+}$(differentiated) RGCs. Scale bars, $250 \mu \mathrm{m}$.

\section{Ipsilateral RGCs express early developmental markers}

A large group of genes enriched in ipsilateral RGCs in the microarray were transcription factors known to be important in the development of retinal progenitor cells or RGC precursors. Two possible explanations for this finding include: (1) the ipsilateral RGC sample is disproportionately contaminated with RNA from proliferating cells, or (2) these genes are indeed enriched in ipsilateral RGCs. In support of the latter scenario, two ipsilateral RGCenriched microarray candidates, Sox2 and Math, show clear expression in both progenitor cells and differentiated RGCs (Fig. 6A, B). Sox2 is expressed in neuronal progenitors during CNS development, including the retina, but is downregulated during the final division as the progenitor becomes postmitotic (Pevny and Nicolis, 2010). Indeed, we observed homogeneous Sox2 expression within the proliferative regions of retina, i.e., the neuroblastic layer progenitors, ciliary body progenitors (Fig. 6A), and optic nerve head glial progenitors (not shown). Remarkably, Sox2 is also expressed homogeneously and at an overall stronger level within the Zic2 ${ }^{+}$ VT RGC zone and colocalizes with Zic2 and Islet1/2 expression. Sox2 is completely absent from DT RGCs, indicated by Islet $1 / 2$ expression, including the most pe- ripheral cells. Thus, Sox 2 mRNA expression is maintained in postmitotic Zic2 ${ }^{+}$RGCs and, similar to SERT, is a distinct marker of this RGC subset.

The transcription factor Math5 is expressed in retinal progenitors after they acquire competence to generate RGCs (Wang et al., 2001; Brzezinski et al., 2012) and thus marks the first neurogenic competence state of retinal progenitors (Yang et al., 2003). Similar to Sox2, Math5 mRNA expression extends into the Zic2 ${ }^{+}$RGC zone. However, unlike the homogeneous expression of Sox2, Math5 colocalizes with Zic2 expression predominantly in peripheral RGCs (Fig. 6B, red arrows indicate Zic2 ${ }^{+}$nucleus in red with surrounding Math5 mRNA in black). This colocalization is not as pronounced in RGCs in DT retina.

Sox2 and Math5 expression patterns indicate that ipsilateral RGCs retain the expression of genes initially expressed before differentiation. This may be due to an upstream regulatory program that differs between ipsilateral and contralateral RGCs, turning off the expression of progenitor genes within contralateral RGCs but allowing for their continued expression in ipsilateral RGCs. These results raise the intriguing question of why $\mathrm{Zic}{ }^{+}$ipsilaterally projecting RGCs maintain the expression of such genes. Interestingly, we detected a number of cell cycle regulators enriched in ipsilateral RGCs in our microarray 

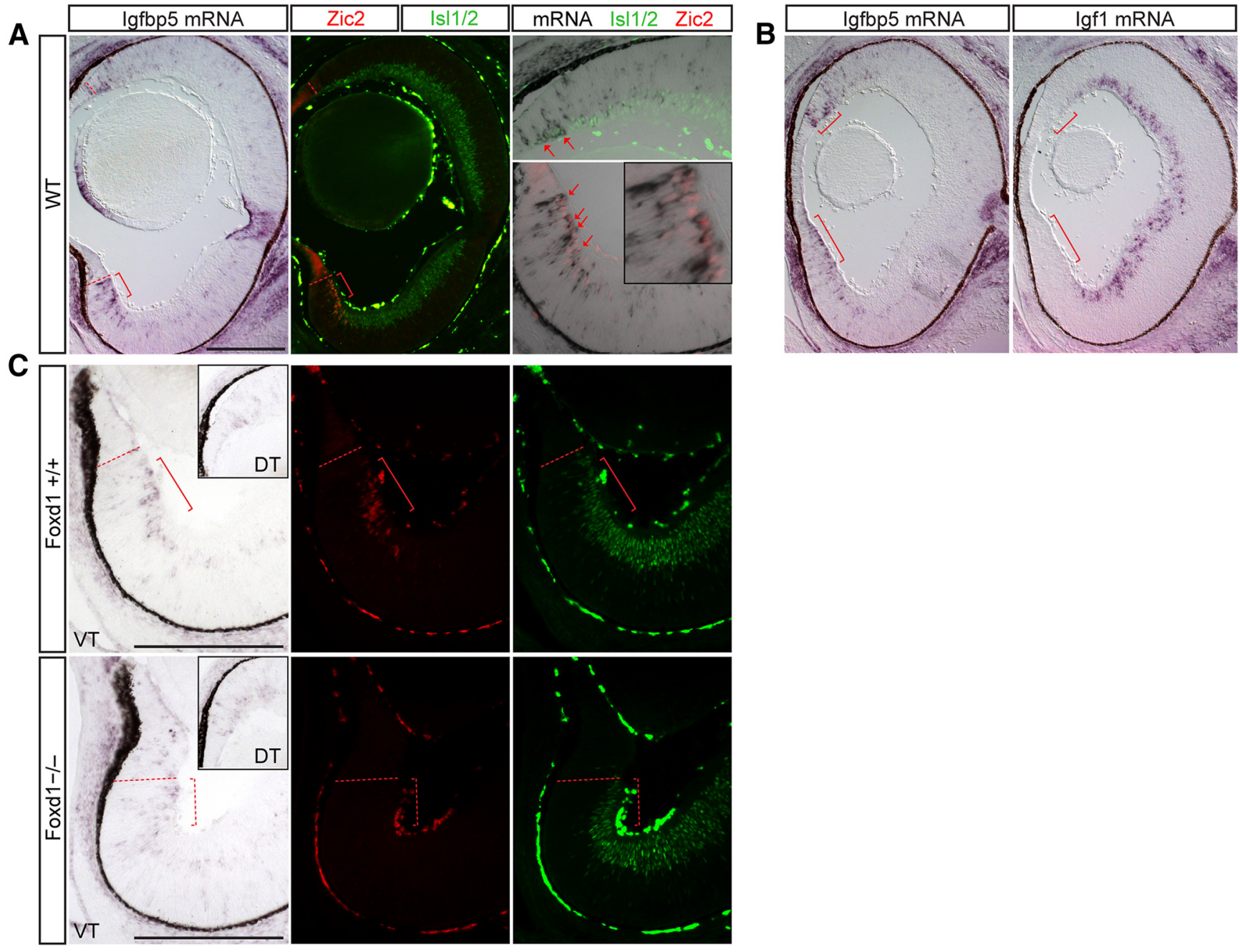

Figure 5. Igfbp5 is expressed in the VT RGC zone in Zic2 ${ }^{+}$cells. ISH analysis at E15.5. $\boldsymbol{A}$, Igfbp5 mRNA is expressed in a subset of Zic2 $^{+}$RGCs in VT retina (red arrows) and a few Zic2 ${ }^{-}$RGCs in dorsal retina. Red brackets mark the ipsilateral RGC domain. $\boldsymbol{B}$, Igfbp5 (red brackets) and lgf1 are expressed in a complementary pattern throughout the retina. $\boldsymbol{C}$, Igfbp5 expression is concomitantly reduced in the Foxd1 KO mutant compared with WT littermates; this reduction correlates with the similar reduction in Zic2 expression in the VT retina of the Foxd1 KO mutant. Red brackets mark the expected ipsilateral RGC domain. Scale bars, $250 \mu \mathrm{m}$.

screen. In particular, the G1 cyclin D2 stood out as an interesting candidate, as its function has not been previously examined in the retina due to the lack of a gross retinal phenotype in cyclin D2 null mice (Sicinski et al., 1996). In contrast, mice without cyclin D1, which is the predominant G1 cyclin during retinal development, have severely hypocellular retinas (Fantl et al., 1995; Sicinski et al., 1995; Dyer and Cepko, 2001; Geng et al., 2001; Das et al., 2009).

In our ISH studies, cyclin D2 (Ccnd2) is expressed asymmetrically in the proliferating cells peripheral to the RGC zone at E15.5, with a higher level and broader zone of expression in ventral retina compared with dorsal retina (Fig. 6C; see also Trimarchi et al., 2009). Moreover, lower levels of cyclin D2 mRNA expression extend into the $\mathrm{Zic2}^{+}$RGC zone but can also be detected at a lower level within the entire span of the Zic2 ${ }^{+}$RGC zone (Fig. $6 C$, inset). The asymmetry in expression and extension of the cyclin D2 domain into the Zic2 ${ }^{+}$RGC zone are even more pronounced at E13.5 (Fig. 6D). Because of the localization of Ccnd2 mRNA to the basal process of these cells, which has been previously described in the cortex (Tsunekawa et al., 2012), we are unable to determine whether Cyclin D2 mRNA and Zic2 protein expression colocalize in the same cells.

To determine cyclin D2 protein localization throughout development, retinal sections from E11.5, 13.5, 14.5, 15.5, and E16.5 embryos were immunostained with antibodies against cyclin D2, Zic2 (ipsilateral RGCs), and Brn3 (all RGCs). Consistent with the ISH results, IHC analysis showed that cyclin D2 is expressed within the retinal periphery and the optic nerve head, and its expression is substantially higher in ventral than in dorsal periphery until E15.5 (Fig. 7A-D). At E16.5, this asymmetry in the ventrodorsal expression of cyclin D2 decreases, as fewer cells now express cyclin D2 in ventral retina (Fig. 7E). In contrast to the ISH results, immunostaining revealed that cyclin D2 protein is nuclear rather than at the basal surface, with cells expressing the highest levels of cyclin D2 positioned more basally. These distinct cyclin D2 mRNA 


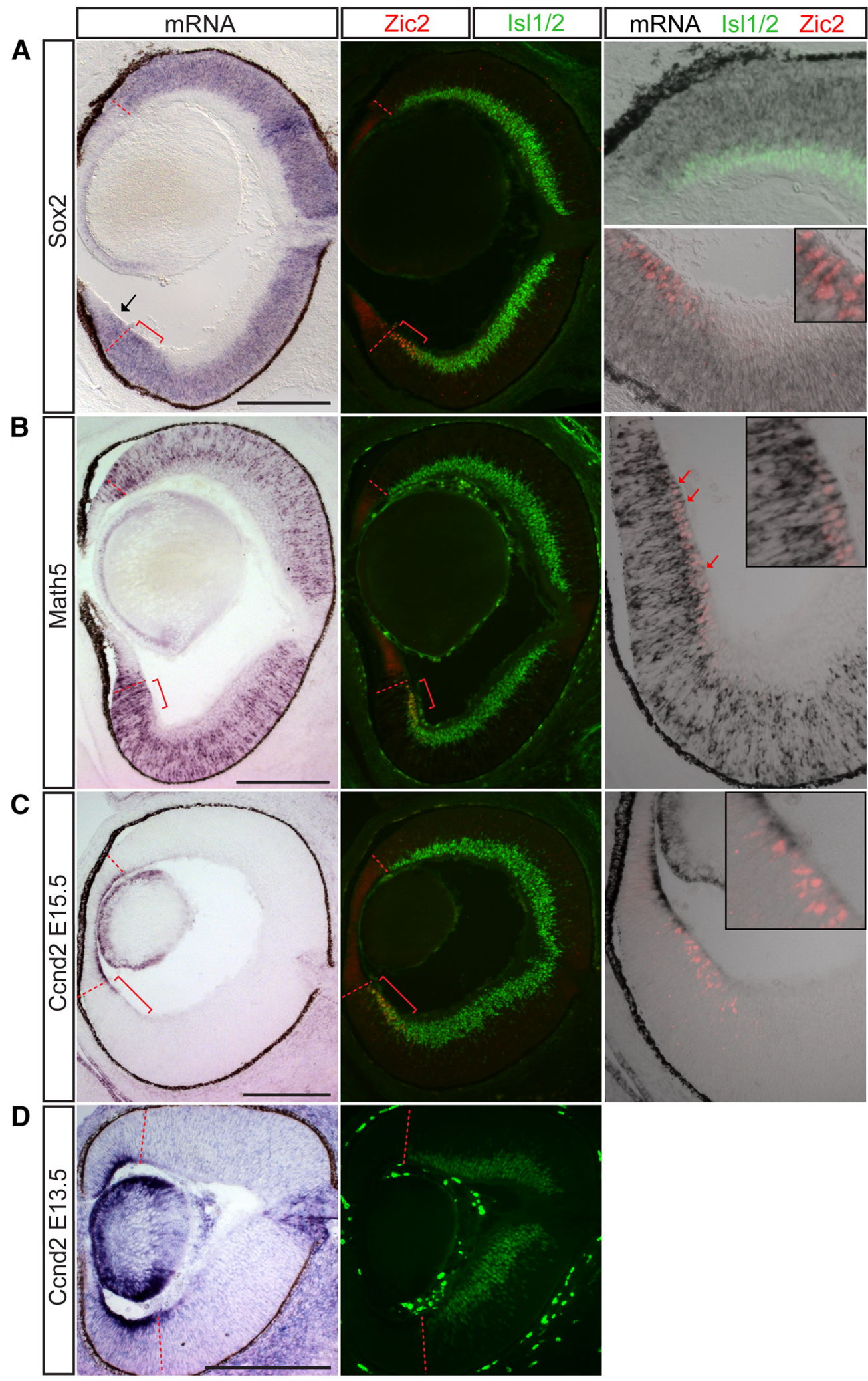

Figure 6. Sox2, Math5, and cyclin D2 are enriched in the ipsilateral RGC population in addition to progenitor cells throughout the retina. ISH analysis at E15.5. A, Sox2 mRNA is expressed in the neuroblastic layer and Zic2 ${ }^{+}$RGCs but not Zic2 $2^{-} /$lslet1/2 $^{+}$(differentiated) RGCs extra-VT retina. $\boldsymbol{B}$, Similarly, Math5 mRNA is expressed in Zic2 ${ }^{+}$RGCs located at the periphery of the VT retina in the RGC layer as well as in RGC precursors in the neuroblastic layer (red arrows). $\boldsymbol{C}$, Cyclin D2 mRNA is expressed in the basal process of cells within the peripheral margin of the retina, particularly in the ventral retina, and also at low levels in the Zic2 ${ }^{+}$RGC zone at E15.5. $\boldsymbol{D}$, The asymmetric expression of cyclin D2, with higher levels in ventral retina, is more pronounced at E13.5. Red brackets mark the Zic2 ${ }^{+}$ipsilateral RGC domain. Scale bars, $250 \mu \mathrm{m}$. 

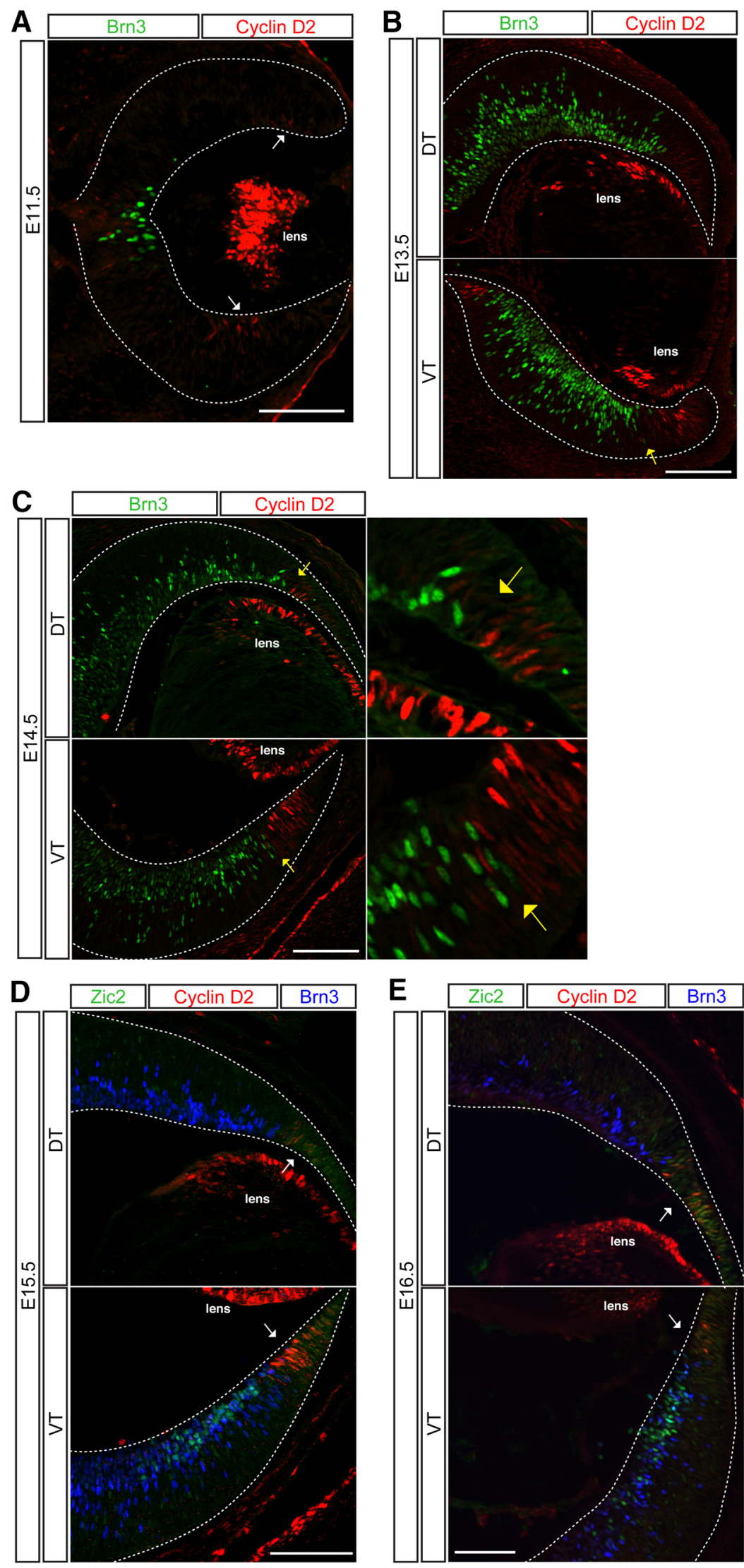

Figure 7. Cyclin D2 is enriched in the ventral peripheral retina during the temporal window of ipsilateral RGC genesis. IHC in coronal cryosections of E11.5 (A), E12.5 $(\boldsymbol{B})$, E14.5 $(\boldsymbol{C}), \mathrm{E} 15.5(\boldsymbol{D})$, and E16.5 $(\boldsymbol{E})$ retina. Cyclin D2 is expressed in the lens and the retinal 
continued

marginal zone bordering RGCs (labeled with Brn3). Cyclin D2 is highly expressed in the ventral periphery compared with the dorsal periphery within neural retina (white arrows). The cyclin D2 and Brn3 domains are separated by a large gap at E11.5 $(\boldsymbol{A})$. At E13.5 (B) and E14.5 $(\boldsymbol{C})$, cyclin D2 ${ }^{+}$cells intermingle with Brn3 ${ }^{+}$RGCs only in ventral retina (yellow arrows point to boundary) and have sharp boundaries in dorsal retina. At E16.5 $(\boldsymbol{E})$, cyclin D2 expression is reduced in the retinal periphery and is no longer asymmetric in dorsal and ventral retinal (white arrows). Scale bars, $100 \mu \mathrm{m}$

and protein expression patterns have been similarly reported in cortex (Tsunekawa and Osumi, 2012). Cyclin $\mathrm{D}^{+}$cells that showed positive staining for Zic2 and Islet1/2 were very rare, indicating that cyclin D2 is expressed predominantly in cells that are situated in the periphery of VT retina, adjacent to the zone of Zic2expressing cells, and do not yet express markers of differentiated RGCs such as Brn3 or Islet1/2. The finding that cyclin D2 is enriched in the ipsilateral RGC population in our microarray analysis and subsequent confirmation by ISH may reflect the perdurance of mRNA expression in differentiated ipsilateral RGCs. The downregulation of cyclin D2 protein expression in differentiated RGCs that express Zic2 and Islet1/2 may be additionally explained by posttranscriptional regulatory mechanisms.

In contrast to cyclin D2, cyclin D1 expression is homogeneous throughout proliferating regions in the retina (data not shown). Cyclin $\mathrm{D}^{+}$cells are also positive for cyclin D1. The broad expression of cyclin D1 is consistent with its role as the major $\mathrm{D}$ cyclin in retinal development required for general retinal histogenesis (Sicinski et al., 1995; Fantl et al., 1995). The additional expression of cyclin D2 in a specific subset of cells within the retina, however, suggests that it conveys an added layer of regulation on the cell cycle kinetics of these cells.

\section{Discussion}

The increasing availability of transcriptomic technologies within the last decade has facilitated high-throughput identification of gene expression profiles that define distinct cell types (Trimarchi et al., 2007; Okaty et al., 2011; Goetz and Trimarchi, 2012; Mizeracka et al., 2013; Islam et al., 2014; Sümbül et al., 2014; Macosko et al., 2015; Molyneaux et al., 2015; Mullally et al., 2016; Shima et al., 2016). Here we have applied DNA microarray analysis to RGCs projecting ipsilaterally and contralaterally during embryonic development. By combining retrograde labeling and cell sorting, we were able to overcome the challenge of isolating a disproportionately sparse neuronal subtype-the ipsilateral RGC population (3-5\% of total RGCs in mouse retina)-and then compared the molecular identity of this population with their contralateral countertypes. These gene-profiling experiments confirmed genes known to be unique to ipsilateral or contralateral RGCs and allowed us to uncover nearly 300 genes that are differentially expressed in these two populations. A number of these genes were subsequently confirmed by endogenous expression in developing retina, thus having high biological relevance. In particular, the new RGC markers expressed solely in contralateral RGCs that we identified fill a significant void, as most genes that have been previously described as important for contralateral RGC function are not exclusively expressed in these cell types but rather are also expressed in ipsilateral RGCs. Among the differentially expressed genes we identified, we have found at least one pair, Igf1 and Igfbp5, that show complementary expression within contralateral and ipsilateral RGCs, respectively, and may represent one of numerous signaling pathways that play a role in determining ipsilateral versus contralateral RGC identity. Finally, we have confirmed the expression of several genes that mark "immaturity" in both ipsilateral RGCs and cells within proliferative zones of the retina. These findings suggest that the ontogeny of ipsilateral and contralateral RGCs and the mechanisms that regulate their differentiation are more diverse than previously expected.

\section{Ipsilateral and contralateral RGCs are molecularly distinct}

Our gene profiling experiments reveal that ipsilateral and contralateral RGCs have distinct molecular signatures and can be distinguished during development not only by their axon guidance programs but also by many genes uncovered in our screen that play diverse functions in growth, differentiation, and fate specification.

To date, the only known specific markers of contralateral RGCs are the LIM homeodomain transcription factor Islet2 and the Pou-domain transcription factor Brn3a (Pou4f1). However, loss of Brn3a does not influence RGC axon laterality (Quina et al., 2005), and whereas Islet2 is important for contralaterality in late-born VT RGCs, it is not required for the major contralateral projection from extra-VT retina (Pak et al., 2004). Moreover, Islet2 is expressed in only a subset of contralateral RGCs. Thus, a transcription factor that specifies contralateral identity throughout the retina has not yet been identified. Our microarray study has revealed a number of different transcription factors that may fill such a role as a transcriptional regulator of contralateral RGC identity.

Together, Igf1, Fgf12, Tbx20, and Sema3e represent four new contralateral RGC markers during the peak period of RGC axon outgrowth. None of these genes have been studied in the context of RGC development. Tbx20 functions in heart development (Plageman and Yutzey, 2005) and cranial motor neuron migration (Song et al., 2006). The expression and guidance roles of semaphorin family members have been demonstrated at multiple points along the path of retinal axons (Callander et al., 2007; Kuwajima et al., 2012). Sema3e is known to be expressed at the optic chiasm (Sakai and Halloran, 2006), where it influences midline crossing decisions in the fish optic chiasm. Here, we show that it is also expressed in a subset of contralateral RGCs, raising the question of why this repulsive guidance cue is also expressed by RGCs. One possible explanation is the demonstration that RGC-secreted Sema3e regulates retinal angiogenesis through interactions with Plexin-D1 expressed 
on endothelial cells of sprouting blood vessels (Callander et al., 2007). However, whether Sema3e has a further function in regulating contralateral RGC axon growth and guidance has not been explored.

Furthermore, the expression of Tbx20 and Sema3e in a mosaic pattern in central retina suggests that both genes may mark a functional subtype of contralateral RGCs that is present only in central retina or in a subset that arises later in development. Alternatively, Tbx20 and Sema3e expression may be delayed in RGCs and thus only seen in the oldest RGCs present at this age, with those in central retina being the first to develop. Consistent with both of these explanations, both Sema3e and Tbx20 are not yet expressed in RGCs at E13.5 (data not shown).

We have also found that Igf1 and Fgf12 are upregulated in contralateral RGCs. The Igf and Fgf signaling pathways have broad mitogenic and cell survival effects during development, tissue repair, and tumor growth. Interestingly, unlike most secreted FGF family members, Fgf12 localizes to the nucleus (Smallwood et al., 1996), and thus may play a cell-autonomous role in RGCs. Igf1 is enriched in contralateral RGCs, whereas Igfbp5 is enriched in ipsilateral RGCs. Further suggesting the complementary expression pattern of these two genes, the most peripheral DT RGCs that lack Igf1 expression, express Igfbp5. However, because this observation was made correlatively by comparing ISH for these two genes on different retinal sections, definitive demonstration of mutually exclusive expression would require double-ISH within the same sections over different developmental time points. Although Igfbp5 is the only Igf binding protein detected by this microarray study, another lgf peptide, Igf2, was enriched in the ipsilateral RGC population. Igf2 has been previously reported as a gene preferentially expressed in peripheral mouse retina (Trimarchi et al., 2009).

Igf1 has also been implicated in neuronal circuitry formation by promoting axon outgrowth in corticospinal motor neurons (Ozdinler and Macklis, 2006) and by acting as a chemoattractant that directs olfactory neuron axons to innervate the lateral olfactory bulb (Scolnick et al., 2008). Insulin receptor signaling has also been implicated in synapse maturation and density within the Xenopus retinotectal circuit (Chiu et al., 2008). More recently, Igf1 has also been shown to promote $\alpha$ RGC-specific regeneration after axotomy (Duan et al., 2015). With its expression of multiple Igf signaling pathway proteins in distinct RGC populations, the developing retina offers an excellent opportunity to study the roles of these genes in neuronal development: in particular, the function of the complimentary genes Igf1 and Igfbp5 in defining the ipsilateral and contralateral RGC population or sectors of the retina.

\section{Ipsilateral RGCs are developmentally less mature than contralateral RGCs}

One highlight of our gene profiling results is that ipsilateral but not contralateral RGCs express multiple transcription factors, such as Math5 and Sox2, known to be expressed in retinal progenitor cells (Xie et al., 2014). Two possible explanations for these observations are that (1) Zic2 $^{+}$RGCs are developmentally less mature than their contralateral counterparts, and failure to downregulate these genes reflect their immaturity, and (2) these progenitor cell markers have additional functions in postmitotic Zic2 $^{+}$RGCs and neuronal subtype identity and function. Indeed, several recent studies suggest that neural progenitor genes also have distinct functional roles in postmitotic neurons. Expression of early eye field transcription factors has been shown in both retinal progenitors and differentiated retinal cell types. For example, Pax6 is expressed in both retinal progenitors and RGCs and has a functional role in postmitotic RGC axonal guidance (Hsieh and Yang, 2009; Sebastián-Serrano et al., 2012). Similarly, although Sox2 is traditionally thought to maintain neural progenitor identity (Graham et al., 2003), it has also been demonstrated to play a role in neuronal differentiation (Cavallaro et al., 2008, Heavner et al., 2014). In the retina, complete Sox2 ablation leads to dramatic loss of neural progenitors; however, reduction of Sox2 expression in hypomorphic or null compound heterozygotes leads to maturation defects specific to RGCs, whereas other cell types are mostly unaffected (Taranova et al., 2006).

Expression of progenitor genes in ipsilateral RGCs can be caused by perdurance of progenitor mRNAs in postmitotic RGCs and may simply reflect the relative neoteny of ipsilateral compared with contralateral RGCs. Alternatively, this expression may suggest that ipsilateral RGCs derive from a progenitor pool at a different competence, or differentiation, stage. Thus, the temporal control of neuronal differentiation may be a specific feature or regulator of ipsilateral versus contralateral RGC fate. In this vein, the same VT region that gives rise to ipsilateral RGCs during earlier retinal growth switches to generating contralaterally projecting RGCs after E16. The importance of timing in controlling fate specification of cell class in the retina (Livesey and Cepko, 2001) and elsewhere in the CNS (Caviness et al., 2003), as well as divergent of the same subclass (Imamura et al., 2011), supports this hypothesis.

\section{Cell cycle regulation in control of RGC subtype differentiation: a role for cyclin D2?}

In support of the preponderance of early genes expressed in ipsilateral RGCs and ventrotemporal retina, we found that cyclin D2 is enriched in ventral retina, although not exclusively expressed there. One potential mechanism for controlling the timing of cell cycle exit and differentiation is through differential expression of cell cycle regulators (Dyer and Cepko, 2001; Ross, 2011). Thus, the finding that cyclin D2 is expressed within the VT RGC zone is particularly interesting. Cyclin D1 is the G1 cyclin expressed throughout most of retinal development (Sicinski et al., 1995). Although the expression of cyclin D2 in the peripheral margin of the retina has been previously shown as part of large-scale expression analyses (Glickstein et al., 2007; Trimarchi et al., 2009), none of those studies dissected out the changes in cyclin D2 expression along the dorsoventral and nasotemporal axes. Unlike the microphthalmia seen in the cyclin D1-null mouse (Fantl et al., 1995; Sicinski et al., 1995), no gross retinal phenotype has been identified in the cyclin D2-null mouse (Sicinski et al., 1996). Studies in cortical, cerebellar, and 
spinal cord development have demonstrated a cell typespecific dependence on the different cyclin $D$ family members, in particular cyclin D1 versus D2 (Huard et al., 1999; Lukaszewicz and Anderson, 2011; Ross, 2011; Petros et al., 2015). Thus, the distinct expression patterns of cyclin D1 and D2 in retinal development, and the close juxtaposition of cyclin D2 with the highly specialized subpopulation of RGCs projecting ipsilaterally, hint at a potential function of cyclin D2 expression in ipsilateral RGC production. In support of this, we observed an intermingling of cyclin $\mathrm{D}^{+}$cells with $\mathrm{Brn}^{+}{ }^{+} \mathrm{RGCs}$ at E13.5 and E14.5 (Fig. 7B, C, yellow arrows) within ventral but not dorsal retina, where the two expression domains have distinct boundaries. This overlap in the cyclin D2 and RGC domains raises the possibility that the $\mathrm{Ccnd} 2^{+}$cells within this overlapping domain are in the process of differentiating into Brn3 $3^{+}$RGCs. Importantly, asymmetry in cyclin D2 expression is apparent only from E11.5 to E15.5, before or during the period when the majority of ipsilateral RGCs are produced, and no longer at E16.5, when ipsilateral RGC production wanes. Thus, the tightly regulated spatiotemporal expression pattern of cyclin D2 within the murine retina is highly suggestive of a population of cyclin D2-expressing progenitors that gives rise to ipsilateral RGCs. These possibilities are being addressed by ongoing studies in our laboratory.

Prior studies in the albino mouse model have shown that changes in the timing and rate of cell production within the ventrotemporal retina lead to a decrease in ipsilateral RGC production (Bhansali et al., 2014). However, the molecular pathways that regulate this rate remain to be determined. The concerted action of cyclin D1 and D2 on cell cycle exit and length could confer one such regulatory mechanism.

\section{Future perspectives}

The developmental roles of the many genes differentially expressed in ipsilateral and contralateral RGCs will be revealed only through further gain- and loss-offunction experiments, through the use of mutant mouse models or overexpression and knockdown studies by in utero and ex vivo electroporation (Petros et al., 2009a). However, the transcriptomic data and in vivo expression studies we present themselves provide novel insight into the development of ipsilateral and contralateral RGCs and the mechanisms through which neuronal diversification can be accomplished in the retina. Additional studies using similar retrograde labeling and cell sorting approaches to isolate ipsilateral and contralateral RGCs in mature retina can further elucidate how these two cell types are molecularly and functionally distinct beyond development, after injury, and in regeneration. Moreover, our use of rapid retrograde labeling ex vivo to isolate projection neurons that have not yet reached their targets can be applied to the purification of other neuronal subtypes during embryonic ages.

Table 4. Gene ontology analysis of differentially expressed genes.

\begin{tabular}{|c|c|c|c|}
\hline Gene ontology term & Corrected $p$-value & Count in selection & $\%$ Count in selection \\
\hline Cell cycle process & $6.91 \mathrm{E}-16$ & 26 & 9.737827 \\
\hline Cell cycle & $1.56 \mathrm{E}-15$ & 46 & 17.228464 \\
\hline Multicellular organismal development & $6.29 \mathrm{E}-14$ & 75 & 28.089888 \\
\hline Developmental process & $8.59 \mathrm{E}-14$ & 81 & 30.337078 \\
\hline Anatomical structure development & $1.57 \mathrm{E}-13$ & 55 & 20.59925 \\
\hline System development & $1.57 \mathrm{E}-13$ & 51 & 19.101124 \\
\hline Cellular component organization & 3.05E-13 & 48 & 17.977528 \\
\hline Cellular component organization at cellular level & $4.22 \mathrm{E}-13$ & 48 & 17.977528 \\
\hline Cellular component organization or biogenesis & $8.20 \mathrm{E}-12$ & 48 & 17.977528 \\
\hline Cell cycle phase & $9.66 \mathrm{E}-12$ & 22 & 8.2397 \\
\hline Cellular component organization or biogenesis at cellular level & 1.33E-11 & 48 & 17.977528 \\
\hline Multicellular organismal process & 4.19E-11 & 75 & 28.089888 \\
\hline Cell division & $1.10 \mathrm{E}-10$ & 28 & 10.486892 \\
\hline Nervous system development & $3.68 \mathrm{E}-10$ & 33 & 12.35955 \\
\hline M phase & $3.74 \mathrm{E}-10$ & 22 & 8.2397 \\
\hline Organelle organization & $1.32 \mathrm{E}-08$ & 39 & 14.606742 \\
\hline Cellular developmental process & 1.33E-08 & 41 & 15.355805 \\
\hline Cell differentiation & $1.33 \mathrm{E}-08$ & 41 & 15.355805 \\
\hline Organ development & 1.77E-08 & 29 & 10.8614235 \\
\hline Mitotic cell cycle & 2.37E-08 & 22 & 8.2397 \\
\hline Cellular component assembly at cellular level & $6.85 \mathrm{E}-08$ & 20 & 7.490637 \\
\hline Positive regulation of cellular process & 4.30E-07 & 40 & 14.981274 \\
\hline Positive regulation of biological process & $5.22 \mathrm{E}-07$ & 40 & 14.981274 \\
\hline M phase of mitotic cell cycle & $6.40 \mathrm{E}-07$ & 22 & 8.2397 \\
\hline DNA binding & $9.46 \mathrm{E}-07$ & 73 & 27.340824 \\
\hline Cellular component assembly & $9.46 \mathrm{E}-07$ & 20 & 7.490637 \\
\hline Mitosis & $2.06 \mathrm{E}-06$ & 21 & 7.8651686 \\
\hline Nuclear division & $2.06 \mathrm{E}-06$ & 21 & 7.8651686 \\
\hline Organelle fission & $3.32 \mathrm{E}-06$ & 21 & 7.8651686 \\
\hline Anatomical structure morphogenesis & $5.73 \mathrm{E}-06$ & 16 & 5.9925094 \\
\hline Embryo development & $5.94 \mathrm{E}-06$ & 10 & 3.7453184 \\
\hline Negative regulation of biological process & 8.17E-06 & 19 & 7.116105 \\
\hline Neurogenesis & $1.17 \mathrm{E}-05$ & 15 & 5.6179776 \\
\hline Organ morphogenesis & $2.01 \mathrm{E}-05$ & 11 & 4.11985 \\
\hline Regulation of cell proliferation & 2.10E-05 & 27 & 10.11236 \\
\hline Cellular macromolecular complex assembly & $\begin{array}{l}2.11 \mathrm{E}-05 \\
\text { (Continued) }\end{array}$ & 20 & 7.490637 \\
\hline
\end{tabular}


Table 4. Continued

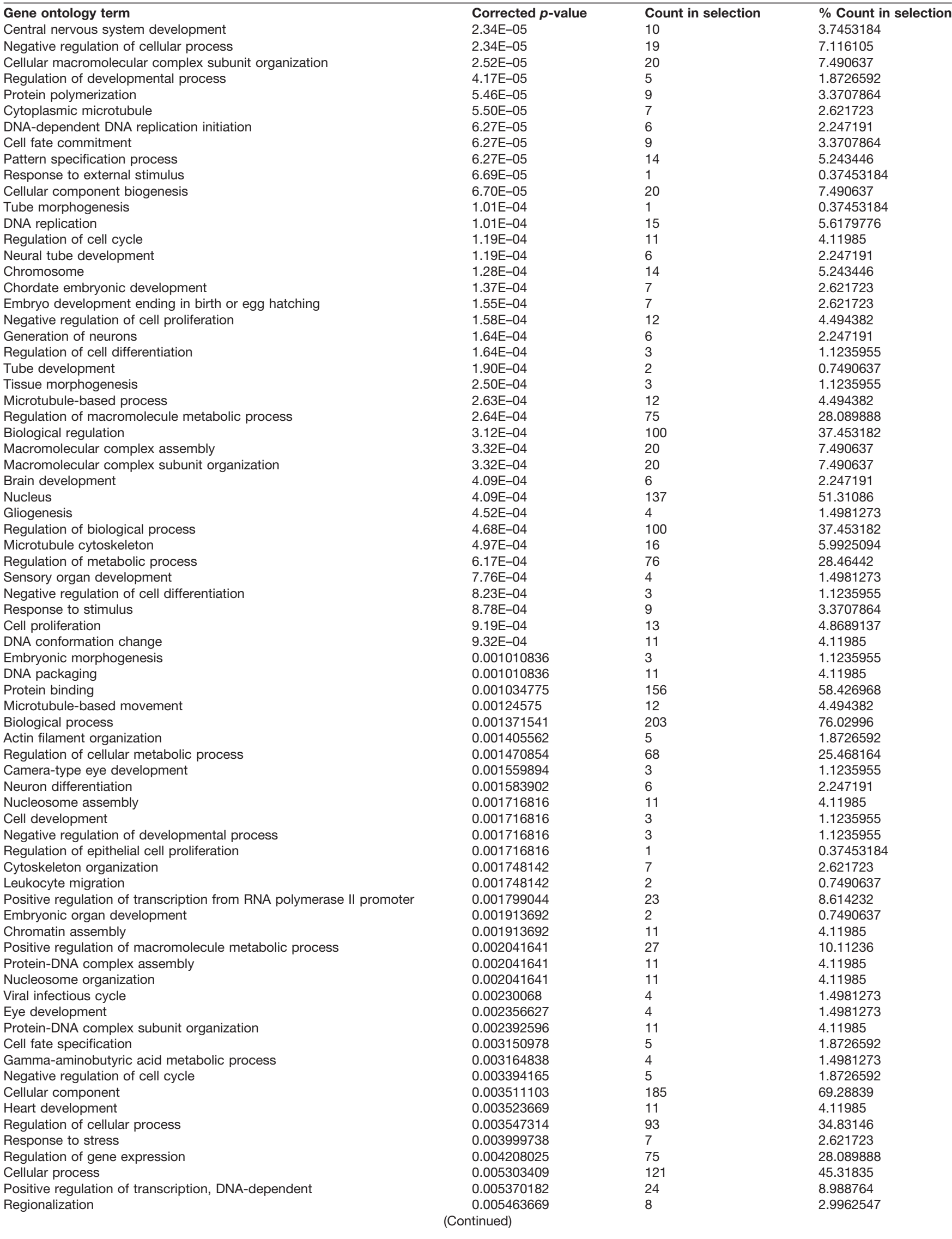


Table 4. Continued

\begin{tabular}{|c|c|c|c|}
\hline $\begin{array}{l}\text { Gene ontology term } \\
\text { Positive regulation of cell proliferation }\end{array}$ & $\begin{array}{l}\text { Corrected } p \text {-value } \\
0.005663401\end{array}$ & $\begin{array}{l}\text { Count in selection } \\
14\end{array}$ & $\begin{array}{l}\text { \% Count in selection } \\
5.243446\end{array}$ \\
\hline Response to wounding & 0.005722695 & 4 & 1.4981273 \\
\hline Positive regulation of RNA metabolic process & 0.005722695 & 24 & 8.988764 \\
\hline Positive regulation of metabolic process & 0.007105737 & 27 & 10.11236 \\
\hline Glial cell differentiation & 0.007105737 & 3 & 1.1235955 \\
\hline Hindbrain development & 0.007105737 & 2 & 0.7490637 \\
\hline $\mathrm{O}$-fucosylpeptide 3-beta- $\mathrm{N}$-acetylglucosaminyltransferase activity & 0.007105737 & 3 & 1.1235955 \\
\hline Dorsal/ventral pattern formation & 0.008772324 & 8 & 2.9962547 \\
\hline Embryonic organ morphogenesis & 0.008772324 & 1 & 0.37453184 \\
\hline Epidermis morphogenesis & 0.008772324 & 1 & 0.37453184 \\
\hline Cytoskeletal part & 0.009421547 & 15 & 5.6179776 \\
\hline Tissue development & 0.009551329 & 5 & 1.8726592 \\
\hline Cellular component movement & 0.009551329 & 6 & 2.247191 \\
\hline
\end{tabular}

Table 5. Genes differentially expressed in ipsilateral versus contralateral RGCs.

\begin{tabular}{|c|c|c|c|c|c|}
\hline Probe set ID & Gene symbol & Fold change & $p$-value & Regulation & Entrez gene ID \\
\hline 1437726_x_at & $\mathrm{C} 1 \mathrm{qb}$ & 63.10 & 0.0001 & Up & 12260 \\
\hline 1448591_at & Ctss & 36.91 & 0.0003 & Up & 13040 \\
\hline 1452141_a_at & Sepp1 & 31.76 & 0.0000 & Up & 20363 \\
\hline 1436905_x_at & Laptm5 & 21.92 & 0.0040 & Up & 16792 \\
\hline 1448617_at & Cd53 & 19.88 & 0.0023 & Up & 12508 \\
\hline 1450792_at & Tyrobp & 17.54 & 0.0012 & Up & 22177 \\
\hline 1427683_at & Egr2 & 17.35 & 0.0002 & Up & 13654 \\
\hline 1419561_at & $\mathrm{Ccl} 3$ & 17.30 & 0.0005 & Up & 20302 \\
\hline 1422903_at & Ly86 & 14.98 & 0.0002 & Up & 17084 \\
\hline 1418204_s_at & Aif1 & 14.64 & 0.0011 & Up & 11629 \\
\hline 1415800_at & Gja1 & 13.85 & 0.0015 & Up & 14609 \\
\hline 1438945_x_at & Gja1 & 11.25 & 0.0012 & Up & 14609 \\
\hline 1433933_s_at & Slco2b1 & 10.56 & 0.0014 & Up & 101488 \\
\hline 1419873_s_at & Csf1r & 10.41 & 0.0006 & Up & 12978 \\
\hline 1415931_at & $\operatorname{lgf} 2$ & 9.71 & 0.0006 & Up & 16002 \\
\hline 1427682_a_at & Egr2 & 9.51 & 0.0005 & Up & 13654 \\
\hline 1426340_at & Slc1a3 & 9.47 & 0.0020 & Up & 20512 \\
\hline 1431724_a_at & P2ry12 & 9.41 & 0.0003 & Up & 70839 \\
\hline 1431057_a_at & Prss23 & 9.39 & 0.0006 & Up & 76453 \\
\hline 1417457_at & Cks2 & 9.15 & 0.0032 & Up & 66197 \\
\hline 1460180_at & Hexb & 8.92 & 0.0003 & Up & 15212 \\
\hline 1448891_at & Fcrls & 8.72 & 0.0021 & Up & 80891 \\
\hline 1438658_a_at & S1pr3 & 8.58 & 0.0013 & Up & 13610 \\
\hline 1456140_at & LOC100045988 & 7.47 & 0.0011 & Up & 100045988 \\
\hline 1416967_at & Sox2 & 7.46 & 0.0287 & Up & 20674 \\
\hline 1417394_at & Klf4 & 7.38 & 0.0000 & Up & 16600 \\
\hline 1439902_at & C5ar1 & 7.38 & 0.0078 & Up & 12273 \\
\hline 1451318_a_at & LOC676654///Lyn & 7.24 & 0.0024 & Up & $17096 / / / 676654$ \\
\hline 1426454_at & Arhgdib & 7.17 & 0.0030 & Up & 11857 \\
\hline 1437874_s_at & \multicolumn{4}{|c|}{ (Continued) } & 15212 \\
\hline
\end{tabular}


Table 5. Continued

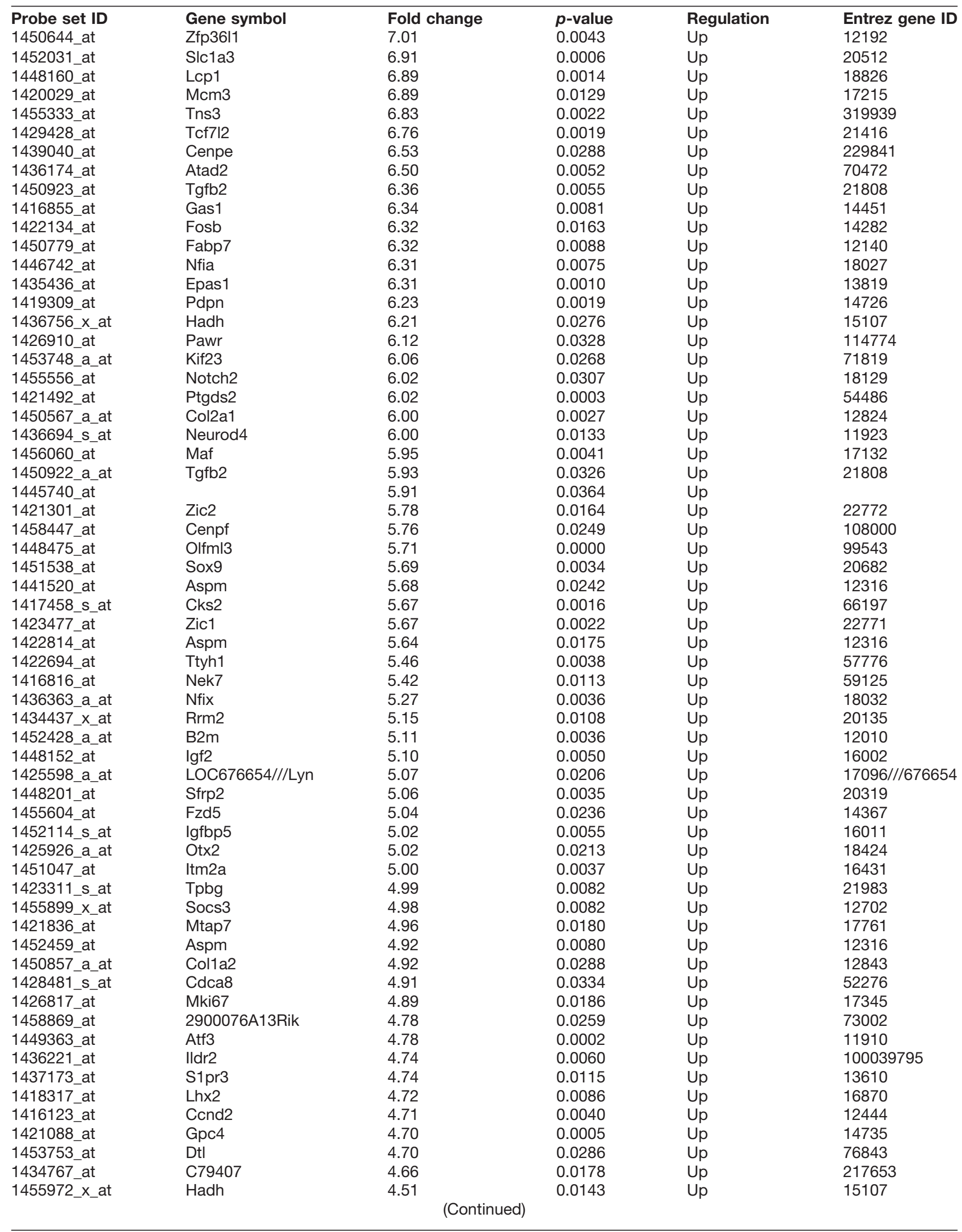


Table 5. Continued

\begin{tabular}{|c|c|c|c|c|c|}
\hline Probe set ID & Gene symbol & Fold change & $p$-value & Regulation & Entrez gene ID \\
\hline 1459894_at & lqgap2 & 4.51 & 0.0151 & Up & 544963 \\
\hline 1452217_at & Ahnak & 4.50 & 0.0059 & Up & 66395 \\
\hline 1417150_at & Slc6a4 & 4.49 & 0.0038 & Up & 15567 \\
\hline 1428105_at & Tpx2 & 4.43 & 0.0147 & Up & 72119 \\
\hline 1423100_at & Fos & 4.39 & 0.0007 & Up & 14281 \\
\hline 1417073_a_at & Qk & 4.39 & 0.0147 & Up & 19317 \\
\hline 1447488_at & & 4.26 & 0.0093 & Up & \\
\hline 1418289_at & Nes & 4.26 & 0.0059 & Up & 18008 \\
\hline 1421163_a_at & Nfia & 4.23 & 0.0112 & Up & 18027 \\
\hline 1437244_at & Gas213 & 4.21 & 0.0056 & Up & 237436 \\
\hline 1420028_s_at & LOC100045677///Mcm3 & 4.18 & 0.0065 & Up & $100045677 / / / 17215$ \\
\hline 1439627_at & Zic1 & 4.15 & 0.0237 & Up & 22771 \\
\hline 1437347_at & Ednrb & 4.14 & 0.0278 & Up & 13618 \\
\hline 1437626_at & Zfp36l2 & 4.14 & 0.0126 & Up & 12193 \\
\hline 1438303_at & Tgfb2 & 4.13 & 0.0316 & Up & 21808 \\
\hline 1440924_at & Kif20b & 4.11 & 0.0375 & Up & 240641 \\
\hline 1436293_x_at & Ildr2 & 4.11 & 0.0263 & Up & 100039795 \\
\hline 1435963_at & Sema5b & 4.11 & 0.0067 & Up & 20357 \\
\hline 1436329_at & Egr3 & 4.11 & 0.0055 & Up & 13655 \\
\hline 1448734_at & $\mathrm{Cp}$ & 4.09 & 0.0167 & Up & 12870 \\
\hline 1417534_at & Itgb5 & 4.07 & 0.0004 & Up & 16419 \\
\hline 1431115_at & Tgif2 & 4.07 & 0.0031 & Up & 228839 \\
\hline 1448229_s_at & Ccnd2 & 4.05 & 0.0247 & Up & 12444 \\
\hline 1426639_a_at & Tcf7l2 & 4.01 & 0.0112 & Up & 21416 \\
\hline 1449705_x_at & LOC100045677///Mcm3 & 3.99 & 0.0024 & Up & $100045677 / / / 17215$ \\
\hline 1450781_at & Hmga2 & 3.98 & 0.0068 & Up & 15364 \\
\hline 1448606_at & Lpar1 & 3.96 & 0.0042 & Up & 14745 \\
\hline 1449289_a_at & $\mathrm{B} 2 \mathrm{~m}$ & 3.95 & 0.0029 & Up & 12010 \\
\hline 1428142_at & Etv5 & 3.92 & 0.0093 & Up & 104156 \\
\hline 1425811_a_at & Csrp1 & 3.92 & 0.0187 & Up & 13007 \\
\hline 1416309_at & Nusap1 & 3.91 & 0.0222 & Up & 108907 \\
\hline 1421317_x_at & Myb & 3.91 & 0.0273 & Up & 17863 \\
\hline 1423586_at & Axl & 3.89 & 0.0002 & Up & 26362 \\
\hline 1417419_at & Ccnd1 & 3.88 & 0.0228 & Up & 12443 \\
\hline 1422929_s_at & Atoh7 & 3.87 & 0.0095 & Up & 53404 \\
\hline 1450379_at & Msn & 3.83 & 0.0013 & Up & 17698 \\
\hline 1448363_at & Yap1 & 3.82 & 0.0007 & Up & 22601 \\
\hline 1455990_at & Kif23 & 3.82 & 0.0069 & Up & 71819 \\
\hline 1428786_at & Nckap1l & 3.80 & 0.0034 & Up & 105855 \\
\hline 1425457_a_at & Grb10 & 3.79 & 0.0182 & Up & 14783 \\
\hline 1450843_a_at & Serpinh1 & 3.78 & 0.0023 & Up & 12406 \\
\hline 1415945_at & Mcm5 & 3.77 & 0.0066 & Up & 17218 \\
\hline 1417911_at & Ccna2 & 3.77 & 0.0354 & Up & 12428 \\
\hline 1419943_s_at & Ccnb1 & 3.77 & 0.0110 & Up & 268697 \\
\hline 1449577_x_at & Tpm2 & 3.76 & 0.0048 & Up & 22004 \\
\hline 1423852_at & Shisa2 & 3.76 & 0.0050 & Up & 219134 \\
\hline 1460291_at & Cdk6 & 3.74 & 0.0015 & Up & 12571 \\
\hline 1424603_at & Sumf1 & 3.72 & 0.0265 & Up & 58911 \\
\hline 1448519_at & Tead2 & 3.72 & 0.0072 & Up & 21677 \\
\hline 1417506_at & Gmnn & 3.70 & 0.0248 & Up & 57441 \\
\hline 1416340_a_at & Man2b1 & 3.69 & 0.0020 & Up & 17159 \\
\hline 1419944_at & Ccnb1 & 3.69 & 0.0190 & Up & 268697 \\
\hline 1426341_at & Slc1a3 & 3.65 & 0.0013 & Up & 20512 \\
\hline 1417395_at & KIf4 & 3.65 & 0.0030 & Up & 16600 \\
\hline 1429189_at & Arsb & 3.65 & 0.0062 & Up & 11881 \\
\hline 1436708_x_at & Mcm4 & 3.64 & 0.0223 & Up & 17217 \\
\hline 1442340_x_at & Cyr61 & 3.62 & 0.0172 & Up & 16007 \\
\hline 1418912_at & Plxdc2 & 3.59 & 0.0032 & Up & 67448 \\
\hline 1417494_a_at & $\mathrm{Cp}$ & 3.59 & 0.0260 & Up & 12870 \\
\hline 1454834_at & Nfib & 3.58 & 0.0047 & Up & 18028 \\
\hline 1452954_at & Ube2c & 3.58 & 0.0329 & Up & 68612 \\
\hline 1420904_at & Il17ra & 3.56 & 0.0026 & Up & 16172 \\
\hline 1434079_s_at & Mcm2 & 3.55 & 0.0083 & Up & 17216 \\
\hline \multicolumn{6}{|c|}{ (Continued) } \\
\hline
\end{tabular}


Table 5. Continued

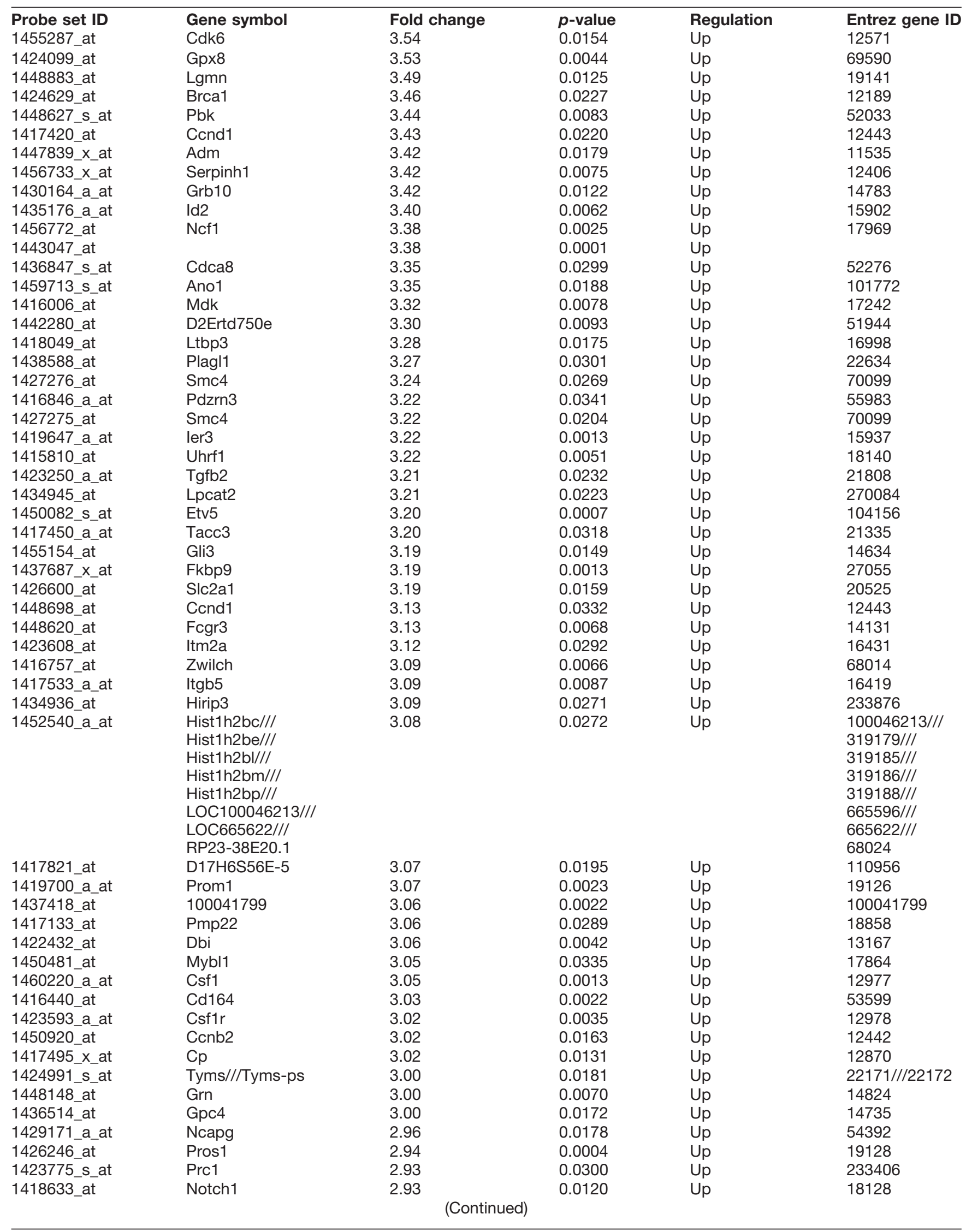


Table 5. Continued

\begin{tabular}{|c|c|c|c|c|c|}
\hline Probe set ID & Gene symbol & Fold change & $p$-value & Regulation & Entrez gene ID \\
\hline 1437478_s_at & Efhd2 & 2.92 & 0.0031 & Up & 27984 \\
\hline 1416368_at & Gsta4 & 2.92 & 0.0003 & Up & 14860 \\
\hline 1450686_at & Pon2 & 2.91 & 0.0118 & Up & 330260 \\
\hline 1450020_at & Cx3cr1 & 2.90 & 0.0203 & Up & 13051 \\
\hline 1418340_at & Fcer1g & 2.87 & 0.0006 & Up & 14127 \\
\hline 1422445_at & Itga6 & 2.87 & 0.0006 & Up & 16403 \\
\hline 1420643_at & Lfng & 2.86 & 0.0033 & Up & 16848 \\
\hline 1448314_at & Cdc2a & 2.86 & 0.0183 & Up & 12534 \\
\hline 1444257_at & Prr11 & 2.84 & 0.0147 & Up & 270906 \\
\hline 1428227_at & Rest & 2.84 & 0.0252 & Up & 19712 \\
\hline 1417947_at & Pcna & 2.77 & 0.0086 & Up & 18538 \\
\hline 1422444_at & $\operatorname{ltga6}$ & 2.76 & 0.0054 & Up & 16403 \\
\hline 1420820_at & 2900073G15Rik & 2.75 & 0.0247 & Up & 67268 \\
\hline 1455393_at & $\mathrm{Cp}$ & 2.75 & 0.0072 & Up & 12870 \\
\hline 1433490_s_at & Epb4.112 & 2.75 & 0.0027 & Up & 13822 \\
\hline 1442728_at & & 2.70 & 0.0124 & Up & \\
\hline 1422612_at & Hk2 & 2.69 & 0.0005 & Up & 15277 \\
\hline 1424604_s_at & Sumf1 & 2.68 & 0.0215 & Up & 58911 \\
\hline 1425271_at & Psmc3ip & 2.68 & 0.0137 & Up & 19183 \\
\hline 1450533_a_at & Plagl1 & 2.67 & 0.0280 & Up & 22634 \\
\hline 1456567_x_at & Grn & 2.67 & 0.0009 & Up & 14824 \\
\hline 1448474_at & Nek7 & 2.65 & 0.0055 & Up & 59125 \\
\hline 1435578_s_at & Dab1 & 2.64 & 0.0240 & Up & 13131 \\
\hline 1416724_x_at & Tcf4 & 2.64 & 0.0110 & Up & 21413 \\
\hline 1449888_at & $\begin{array}{l}\text { Epas1/// } \\
\text { LOC100048537 }\end{array}$ & 2.64 & 0.0166 & Up & $\begin{array}{l}100048537 / / / \\
13819\end{array}$ \\
\hline 1417878_at & E2f1 & 2.64 & 0.0327 & Up & 13555 \\
\hline 1417483_at & Nfkbiz & 2.63 & 0.0185 & Up & 80859 \\
\hline 1452881_at & Gins2 & 2.62 & 0.0103 & Up & 272551 \\
\hline 1449140_at & Nudcd2 & 2.62 & 0.0150 & Up & 52653 \\
\hline 1444800_at & & 2.61 & 0.0099 & Up & \\
\hline 1416251_at & Mcm6 & 2.61 & 0.0322 & Up & 17219 \\
\hline 1423414_at & Ptgs1 & 2.59 & 0.0093 & Up & 19224 \\
\hline 1420171_s_at & Myh9 & 2.58 & 0.0015 & Up & 17886 \\
\hline 1460184_at & Hadh & 2.57 & 0.0092 & Up & 15107 \\
\hline 1425458_a_at & Grb10 & 2.56 & 0.0193 & Up & 14783 \\
\hline 1417822_at & D17H6S56E-5 & 2.56 & 0.0079 & Up & 110956 \\
\hline \multicolumn{6}{|c|}{ (Continued) } \\
\hline
\end{tabular}


Table 5. Continued

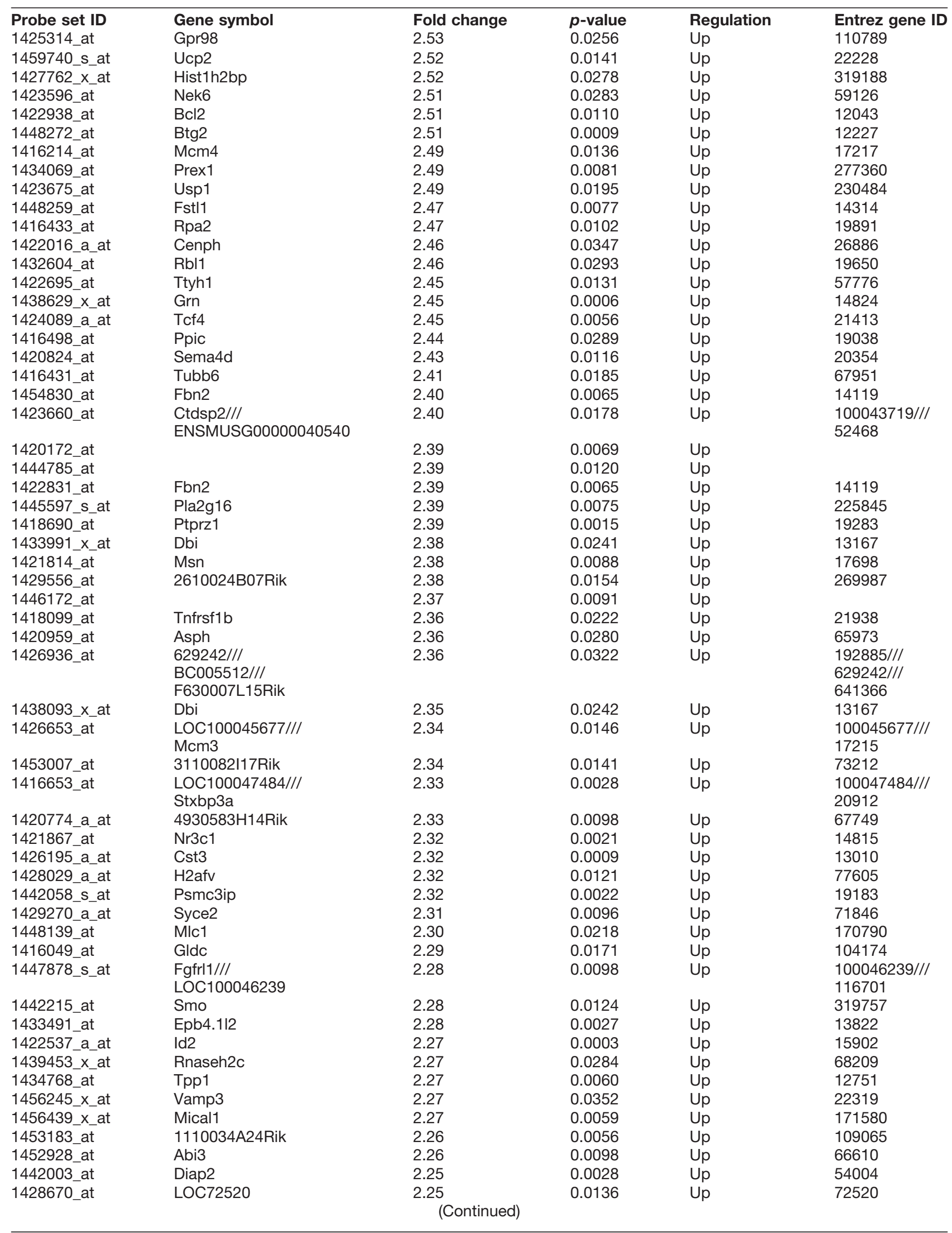


Table 5. Continued

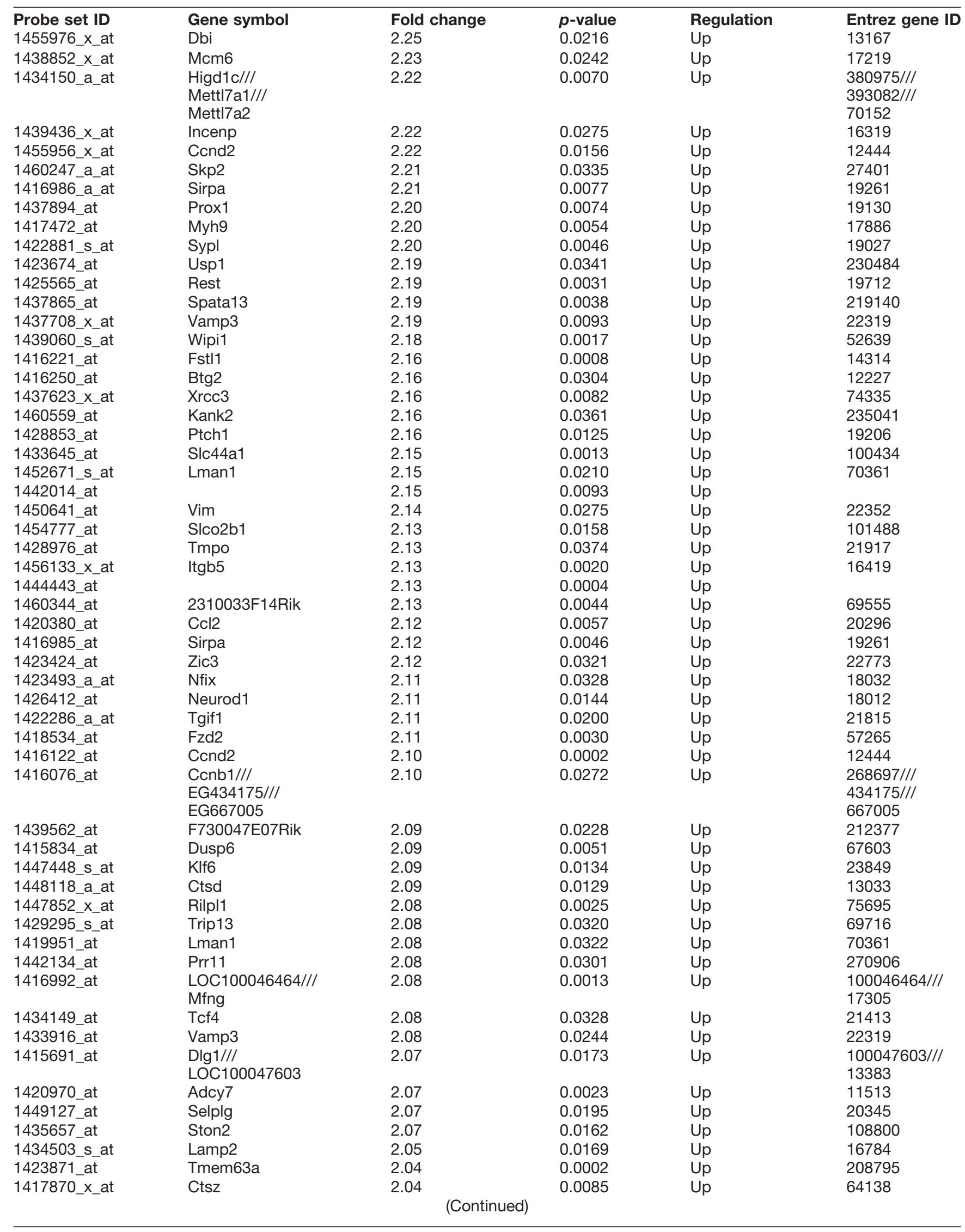


Table 5. Continued

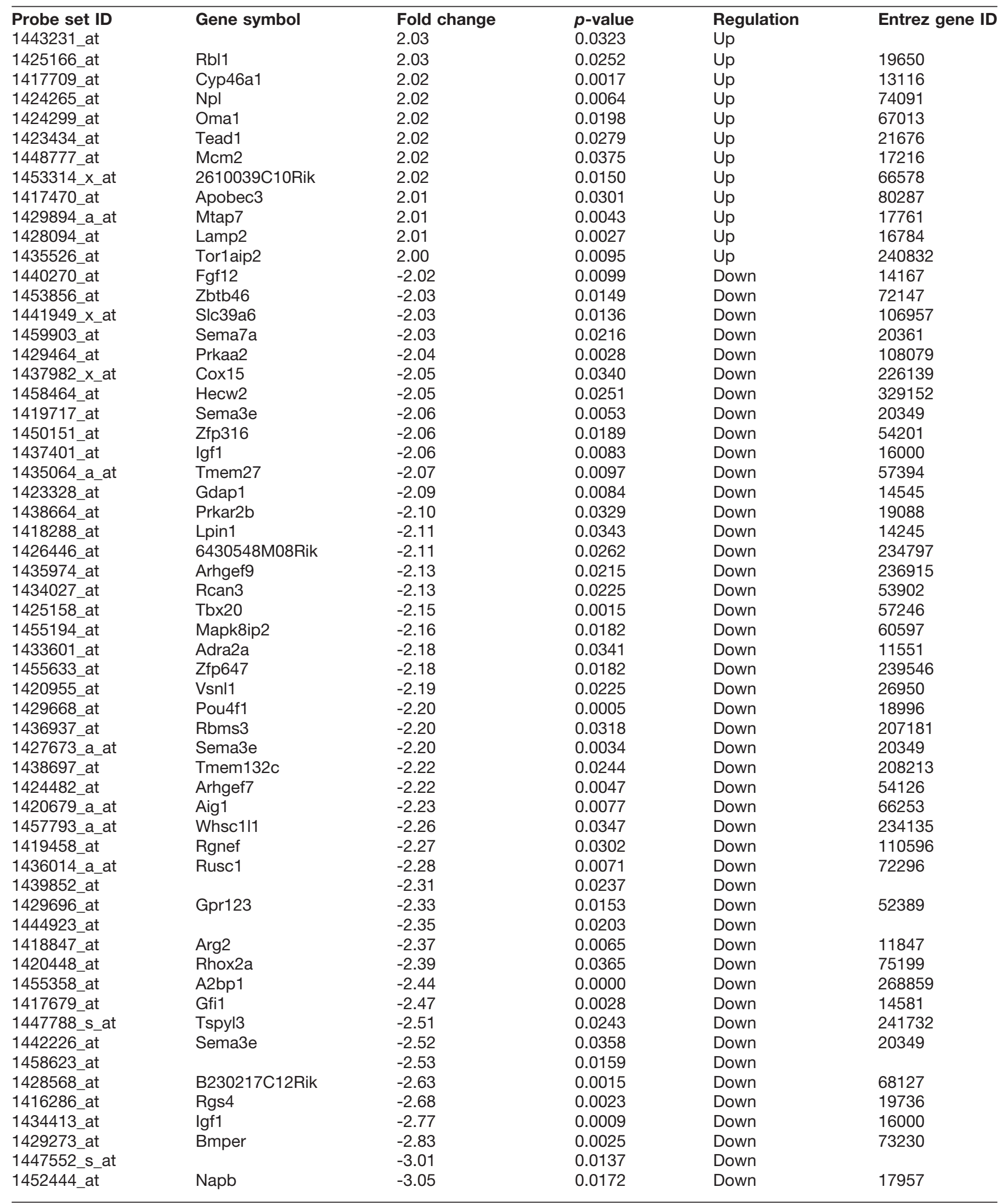

Genes that were enriched by 2 -fold or more with corrected p-value $<=0.05$ in either the ipsilateral or contralateral RGC population were selected for this list. 


\section{References}

Badea T, Cahill H, Ecker J, Hattar S, Nathans J (2009) Distinct roles of transcription factors brn3a and brn3b in controlling the development, morphology, and function of retinal ganglion cells. Neuron 61:852-864. CrossRef

Bhansali P, Rayport I, Rebsam A, Mason C (2014) Delayed neurogenesis leads to altered specification of ventrotemporal retinal ganglion cells in albino mice. Neural Dev 9:11CrossRef Medline

Brzezinski J, Prasov L, Glaser T (2012) Math5 defines the ganglion cell competence state in a subpopulation of retinal progenitor cells exiting the cell cycle. Dev Biol 365:395-413. CrossRef Medline

Callander DC, Lamont RE, Childs SJ, McFarlane S (2007) Expression of multiple class three semaphorins in the retina and along the path of zebrafish retinal axons. Dev Dyn 236:2918-2924. CrossRef Medline

Carreres M, Escalante A, Murillo B, Chauvin G, Gaspar P, Vegar C, Herrera $E$ (2011) Transcription factor Foxd1 is required for the specification of the temporal retina in mammals. J Neurosci 31: 5673-5681. CrossRef

Cavallaro M, Mariani J, Lancini C, Latorre E, Caccia R, Gullo F, Valotta M, Debiasi S, Spinardi L, Ronchi A, Wanke E, Brunelli S, Favaro R, Ottolenghi S, Nicolis SK (2008) Impaired generation of mature neurons by neural stem cells from hypomorphic Sox2 mutants. Development 135:541-557. CrossRef Medline

Caviness VS, JR Goto T, Tarui T, Takahashi T, Bhide PG, Nowakowski RS (2003) Cell output, cell cycle duration and neuronal specification: a model of integrated mechanisms of the neocortical proliferative process. Cereb Cortex 13:592-598. CrossRef

Chiu SL, Chen CM, Cline H (2008) Insulin receptor signaling regulates synapse number, dendritic plasticity, and circuit function in vivo. Neuron 58:708-719. CrossRef

Das G, Choi Y, Sicinski P, Levine E (2009) Cyclin D1 fine-tunes the neurogenic output of embryonic retinal progenitor cells. Neural Dev 4:15 CrossRef Medline

Duan X, Qiao M, Bei F, Kim IJ, He Z, Sanes JR (2015) Subtypespecific regeneration of retinal ganglion cells following axotomy: effects of osteopontin and mTOR signaling. Neuron 85:12441256. CrossRef Medline

Dyer M, Cepko C (2001) Regulating proliferation during retinal development. Nat Rev Neurosci 2:333-342. CrossRef

Erskine L, Reijntjes S, Pratt T, Denti L, Schwarz Q, Vieira J, Alakakone B, Shewan D, Ruhrberg C (2011) VEGF signaling through neuropilin 1 guides commissural axon crossing at the optic chiasm. Neuron 70:951-965. CrossRef Medline

Fantl V, Stamp G, Andrews A, Rosewell I, Dickson C (1995) Mice lacking cyclin D1 are small and show defects in eye and mammary gland development. Genes Dev 9:2364-2372. Medline

Fotaki V, Smith R, Pratt T, Price DJ (2013) Foxg1 is required to limit the formation of ciliary margin tissue and Wnt/beta-catenin signalling in the developing nasal retina of the mouse. Dev Biol 380:299313. CrossRef Medline

Geng Y, Yu Q, Sicinska E, Das M, Bronson R, Sicinski P (2001) Deletion of the p27Kip1 gene restores normal development in cyclin D1-deficient mice. Proc Natl Acad Sci U S A 98:194-199. CrossRef Medline

Glickstein S, Alexander S, Ross M (2007) Differences in cyclin D2 and D1 protein expression distinguish forebrain progenitor subsets. Cereb Cortex (NY) 17:632-642.

Goetz JJ, Trimarchi JM (2012) Single-cell profiling of developing and mature retinal neurons. J Vis Exp pii: 3824.

Graham V, Khudyakov J, Ellis P, Pevny L (2003) SOX2 functions to maintain neural progenitor identity. Neuron 39:749-765. Medline

Hatini V, Tao W, Lai E (1994) Expression of winged helix genes, BF-1 and $B F-2$, define adjacent domains within the developing forebrain and retina. J Neurobiol 25:1293-1309. CrossRef

Heavner WE, Andoniadou CL, Pevny LH (2014) Establishment of the neurogenic boundary of the mouse retina requires cooperation of SOX2 and WNT signaling. Neural Dev 9:27 CrossRef
Hernandez-Bejarano M, Gestri G, Spawls L, Nieto-Lopez F, Picker A, Tada M, Brand M, Bovolenta P, Wilson SW, Cavodeassi F (2015) Opposing Shh and Fgf signals initiate nasotemporal patterning of the zebrafish retina. Development 142:3933-3942.

Herrera E, Brown L, Aruga J, Rachel R, Dolen G, Mikoshiba K, BROWN S, MASON C (2003) Zic2 patterns binocular vision by specifying the uncrossed retinal projection. Cell 114:545-557. CrossRef

Herrera E, Marcus R, Li S, Williams S, Erskine L, Lai E, Mason C (2004) Foxd1 is required for proper formation of the optic chiasm. Development (Cambridge) 131:5727-5739. CrossRef Medline

Hsieh YW, Yang XJ (2009) Dynamic Pax6 expression during the neurogenic cell cycle influences proliferation and cell fate choices of retinal progenitors. Neural Dev 4:32 CrossRef Medline

Huard J, Forster C, Carter M, Sicinski P, Ross M (1999) Cerebellar histogenesis is disturbed in mice lacking cyclin D2. Development (Cambridge) 126:1927-1935. Medline

Imamura F, Ayoub AE, Rakic P, Greer CA (2011) Timing of neurogenesis is a determinant of olfactory circuitry. Nat Neurosci 14: 331-337. CrossRef Medline

Islam S, Zeisel A, Joost S, La Manno G, Zajac P, Kasper M, Lönnerberg P, Linnarsson S (2014) Quantitative single-cell RNAseq with unique molecular identifiers. Nat Methods 11:163-166. CrossRef Medline

Jiang Y, Ding Q, Xie X, Libby RT, Lefebvre V, Gan L (2013) Transcription factors SOX4 and SOX11 function redundantly to regulate the development of mouse retinal ganglion cells. J Biol Chem 288:18429-18438. CrossRef Medline

Jin K, Xiao D, Andersen B, Xiang M (2015) Lmo4 and other LIM domain only factors are necessary and sufficient for multiple retinal cell type development. Dev Neurobiol 76:900-915.

Kay J, de la Huerta I, Kim IJ, Zhang Y, Yamagata M, Chu M, Meister M, Sanes J (2011a) Retinal ganglion cells with distinct directional preferences differ in molecular identity, structure, and central projections. J Neurosci 31:7753-7762.

Kay J, Voinescu P, Chu M, Sanes J (2011b) Neurod6 expression defines new retinal amacrine cell subtypes and regulates their fate. Nat Neurosci 14:965-972. CrossRef Medline

Kim IJ, Zhang Y, Yamagata M, Meister M, Sanes J (2008) Molecular identification of a retinal cell type that responds to upward motion. Nature 452:478-482. CrossRef Medline

Kuwajima T, Yoshida Y, Takegahara N, Petros T, Kumanogoh A, Jessell T, Sakurai T, Mason C (2012) Optic chiasm presentation of Semaphorin6D in the context of Plexin-A1 and Nr-CAM promotes retinal axon midline crossing. Neuron 74:676-690. CrossRef Medline

Livesey F, Cepko C (2001) Vertebrate neural cell-fate determination: lessons from the retina. Nature Rev Neurosci 2:109-118. CrossRef Medline

Lodato S, Arlotta P (2015) Generating neuronal diversity in the mammalian cerebral cortex. Annu Rev Cell Dev Biol 31:699-720. CrossRef Medline

Lukaszewicz A, Anderson D (2011) Cyclin D1 promotes neurogenesis in the developing spinal cord in a cell cycle-independent manner. Proc Natl Acad Sci U S A 108:11632-11637. CrossRef

Macosko EZ, Basu A, Satija R, Nemesh J, Shekhar K, Goldman M, Tirosh I, Bialas AR, Kamitaki N, Martersteck EM, Trombetta JJ, Weitz DA, Sanes JR, Shalek AK, Regev A, McCarroll SA (2015) Highly parallel genome-wide expression profiling of individual cells using nanoliter droplets. Cell 161:1202-1214. CrossRef

Mizeracka K, Demaso CR, Cepko CL (2013) Notch1 is required in newly postmitotic cells to inhibit the rod photoreceptor fate. Development 140:3188-3197. CrossRef

Molyneaux BJ, Goff LA, Brettler AC, Chen HH, Brown JR, Hrvatin S, Rinn JL, Arlotta P (2015) DeCoN: genome-wide analysis of in vivo transcriptional dynamics during pyramidal neuron fate selection in neocortex. Neuron 85:275-288. CrossRef Medline

Mullally $\mathrm{M}$, Albrecht $\mathrm{C}$, Horton M, Laboissonniere LA, Goetz JJ, Chowdhury R, Manning A, Wester AK, Bose Q, Trimarchi JM (2016) Expression profiling of developing zebrafish retinal cells. Zebrafish 13:272-280. 
Okaty B, Sugino K, Nelson S (2011) Cell type-specific transcriptomics in the brain. J Neurosci 31:6939-6943. CrossRef Medline

Osterhout JA, Stafford BK, Nguyen PL, Yoshihara Y, Huberman AD (2015) Contactin-4 mediates axon-target specificity and functional development of the accessory optic system. Neuron 86:985-999. CrossRef Medline

Ozdinler P, Macklis J (2006) IGF-I specifically enhances axon outgrowth of corticospinal motor neurons. Nat Neurosci 9:13711381. CrossRef Medline

Pak W, Hindges R, Lim YS, Pfaff S, O'Leary D (2004) Magnitude of binocular vision controlled by islet-2 repression of a genetic program that specifies laterality of retinal axon pathfinding. Cell 119: 567-578. CrossRef Medline

Pan L, Deng M, Xie X, Gan L (2008) ISL1 and BRN3B co-regulate the differentiation of murine retinal ganglion cells. Development (Cambridge) 135:1981-1990. CrossRef Medline

Petros T, Rebsam A, Mason C (2009a) In utero and ex vivo electroporation for gene expression in mouse retinal ganglion cells. $\mathrm{J}$ Vis Exp pii: 1333

Petros T, Shrestha B, Mason C (2009b) Specificity and sufficiency of EphB1 in driving the ipsilateral retinal projection. J Neurosci 29: 3463-3474. CrossRef Medline

Petros TJ, Bultje RS, Ross ME, Fishell G, Anderson SA (2015) Apical versus basal neurogenesis directs cortical interneuron subclass fate. Cell Rep 13:1090-1095. CrossRef

Pevny L, Nicolis S (2010) Sox2 roles in neural stem cells. Int J Biochem Cell Biol 42:421-424. CrossRef Medline

Picker A, Cavodeassi F, Machate A, Bernauer S, Hans S, Abe G, Kawakami K, Wilson S, Brand M (2009) Dynamic coupling of pattern formation and morphogenesis in the developing vertebrate retina. PLoS Biology 7:e1000214. CrossRef

Plageman TF, Jr, Yutzey KE (2005) T-box genes and heart development: putting the "T" in heart. Dev Dyn 232:11-20. CrossRef Medline

Pratt T, Tian NM, Simpson T, Mason J, Price D (2004) The winged helix transcription factor Foxg1 facilitates retinal ganglion cell axon crossing of the ventral midline in the mouse. Development (Cambridge) 131:3773-3784. CrossRef

Quina L, Pak W, Lanier J, Banwait P, Gratwick K, Liu Y, Velasquez T, O'Leary D, Goulding M, Turner E (2005) Brn3a-expressing retinal ganglion cells project specifically to thalamocortical and collicular visual pathways. J Neurosci 25:11595-11604. CrossRef

Ross M (2011) Cell cycle regulation and interneuron production. Dev Neurobiol 71:2-9. CrossRef Medline

Rousso DL, Qiao M, Kagan RD, Yamagata M, Palmiter RD, Sanes JR (2016) Two pairs of ON and OFF retinal ganglion cells are defined by intersectional patterns of transcription factor expression. Cell Rep 15:1930-1944. CrossRef

Sajgo S, Ghinia MG, Shi M, Liu P, Dong L, Parmhans N, Popescu O, Badea TC (2014) Dre - Cre sequential recombination provides new tools for retinal ganglion cell labeling and manipulation in mice. PLoS One 9:e91435 CrossRef Medline

Sakai JA, Halloran MC (2006) Semaphorin 3d guides laterality of retinal ganglion cell projections in zebrafish. Development 133: 1035-1044. CrossRef Medline

Sanes JR, Masland RH (2015) The types of retinal ganglion cells: current status and implications for neuronal classification. Annu Rev Neurosci 38:221-246. CrossRef Medline

Schaeren-Wiemers N, Gerfin-Moser A (1993) A single protocol to detect transcripts of various types and expression levels in neural tissue and cultured cells: in situ hybridization using digoxigeninlabelled cRNA probes. Histochemistry 100:431-440. CrossRef

Scolnick J, Cui K, Duggan C, Xuan S, Yuan XB, Efstratiadis A, Ngai $J$ (2008) Role of IGF signaling in olfactory sensory map formation and axon guidance. Neuron 57:847-857. CrossRef Medline

Sebastián-Serrano A, Sandonis A, Cardozo M, Rodríguez-Tornos FM, Bovolenta P, Nieto M (2012) Palphax6 expression in postmitotic neurons mediates the growth of axons in response to SFRP1. PLoS One 7:e31590 CrossRef Medline
Shekhar K, Lapan SW, Whitney IE, Tran NM, Macosko EZ, Kowalczyk M, Adiconis X, Levin JZ, Nemesh J, Goldman M, McCarroll SA, Cepko CL, Regev A, Sanes JR (2016) Comprehensive classification of retinal bipolar neurons by single-cell transcriptomics. Cell 166:1308-1323. CrossRef

Shima Y, Sugino K, Hempel CM, Shima M, Taneja P, Bullis JB, Mehta S, Lois C, Nelson SB (2016) A mammalian enhancer trap resource for discovering and manipulating neuronal cell types. Elife 5:e13503. CrossRef

Sicinski P, Donaher J, Geng Y, Parker S, Gardner H, Park M, Robker R, Richards J, McGinnis L, Biggers J, Eppig J, Bronson R, Elledge S, Weinberg R (1996) Cyclin D2 is an FSH-responsive gene involved in gonadal cell proliferation and oncogenesis. Nature 384: 470-474. CrossRef Medline

Sicinski P, Donaher J, Parker S, Li T, Fazeli A, Gardner H, Haslam S, Bronson R, Elledge S, Weinberg R (1995) Cyclin D1 provides a link between development and oncogenesis in the retina and breast. Cell 82:621-630. Medline

Smallwood P, Munoz-Sanjuan I, Tong P, Macke J, Hendry S, Gilbert D, Copeland N, Jenkins N, Nathans J (1996) Fibroblast growth factor (FGF) homologous factors: new members of the FGF family implicated in nervous system development. Proc Natl Acad Sci U S A 93:9850-9857. CrossRef

Song MR, Shirasaki R, Cai CL, Ruiz E, Evans S, Lee SK, Pfaff S (2006) T-Box transcription factor Tbx20 regulates a genetic program for cranial motor neuron cell body migration. Development (Cambridge) 133:4945-4955. CrossRef

Sümbül U, Song $S$, McCulloch K, Becker M, Lin B, Sanes JR, Masland RH, Seung HS (2014) A genetic and computational approach to structurally classify neuronal types. Nat Commun 5:3512 CrossRef Medline

Tang JC, Rudolph S, Dhande OS, Abraira VE, Choi S, Lapan SW, Drew IR, Drokhlyansky E, Huberman AD, Regehr WG, Cepko CL (2015) Cell type-specific manipulation with GFP-dependent Cre recombinase. Nat Neurosci 18:1334-1341. CrossRef Medline

Taranova O, Magness S, Fagan B, Wu Y, Surzenko N, Hutton S, Pevny $L$ (2006) SOX2 is a dose-dependent regulator of retinal neural progenitor competence. Genes Dev 20:1187-1202. CrossRef Medline

Tian N, Pratt T, Price D (2008) Foxg1 regulates retinal axon pathfinding by repressing an ipsilateral program in nasal retina and by causing optic chiasm cells to exert a net axonal growth-promoting activity. Development (Cambridge) 135:4081-4089. CrossRef

Trimarchi J, Cho SH, Cepko C (2009) Identification of genes expressed preferentially in the developing peripheral margin of the optic cup. Dev Dyn 238:2327-2329. CrossRef

Trimarchi J, Stadler M, Roska B, Billings N, Sun B, Bartch B, Cepko C (2007) Molecular heterogeneity of developing retinal ganglion and amacrine cells revealed through single cell gene expression profiling. J Comp Neur 502:1047-1065. CrossRef

Tsunekawa Y, Britto J, Takahashi M, Polleux F, Tan SS, Osumi N (2012) Cyclin D2 in the basal process of neural progenitors is linked to non-equivalent cell fates. EMBO J 31:1879-1892. CrossRef Medline

Tsunekawa Y, Osumi N (2012) How to keep proliferative neural stem/progenitor cells: a critical role of asymmetric inheritance of cyclin D2. Cell Cycle (Georgetown) 11:3550-3554. CrossRef Medline

Wang S, Kim B, Ding K, Wang H, Sun D, Johnson R, Klein W, Gan L (2001) Requirement for math5 in the development of retinal ganglion cells. Genes Dev 15:24-29. Medline

Watson FL, Mills EA, Wang X, Guo C, Chen DF, Marsh-Armstrong N (2012) Cell type-specific translational profiling in the Xenopus laevis retina. Dev Dyn 241:1960-1972. CrossRef Medline

Williams S, Grumet M, Colman D, Henkemeyer M, Mason C, Sakurai $\mathrm{T}$ (2006a) A role for Nr-CAM in the patterning of binocular visual pathways. Neuron 50:535-547. CrossRef Medline

Williams S, Mann F, Erskine L, Sakurai T, Wei S, Rossi D, Gale N, Holt C, Mason C, Henkemeyer M (2003) Ephrin-B2 and EphB1 mediate retinal axon divergence at the optic chiasm. Neuron 39:919-935. Medline 
Williams SE, Grumet M, Colman DR, Henkemeyer M, Mason CA, Sakurai T (2006b) A role for Nr-CAM in the patterning of binocular visual pathways. Neuron 50:535-547. CrossRef Medline

Xie W, Lynch TJ, Liu X, Tyler SR, Yu S, Zhou X, Luo M, Kusner DM, Sun X, Yi Y, Zhang Y, Goodheart MJ, Parekh KR, Wells JM, Xue $\mathrm{HH}$, Pevny LH, Engelhardt JF (2014) Sox2 modulates Lef-1 expression during airway submucosal gland development. Am J Physiol Lung Cell Mol Physiol 306:L645-L660. CrossRef Medline

Yang Z, Ding K, Pan L, Deng M, Gan L (2003) Math5 determines the competence state of retinal ganglion cell progenitors. Dev Biol 264:240-254. Medline 